\title{
OCEAN GENERAL CIRCULATION MODELLING OF THE NORDIC SEAS
}

Helge Drange, Rüdiger Gerdes, Yongqi Gao, Michael Karcher, Frank Kauker, Mats Bentsen

From The Nordic Seas: An Integrated Perspective

H. Drange, T. Dokken, T. Furevik, R. Gerdes and W. Berger (Eds.)

AGU Monograph 158, American Geophysical Union, Washington DC, pp. 199-220.

The official version of the paper is available from AGU

(https://www.agu.org/cgi-bin/agubookstore? memb=agu\&topic=..G M\&book=0 SG M 1584238)

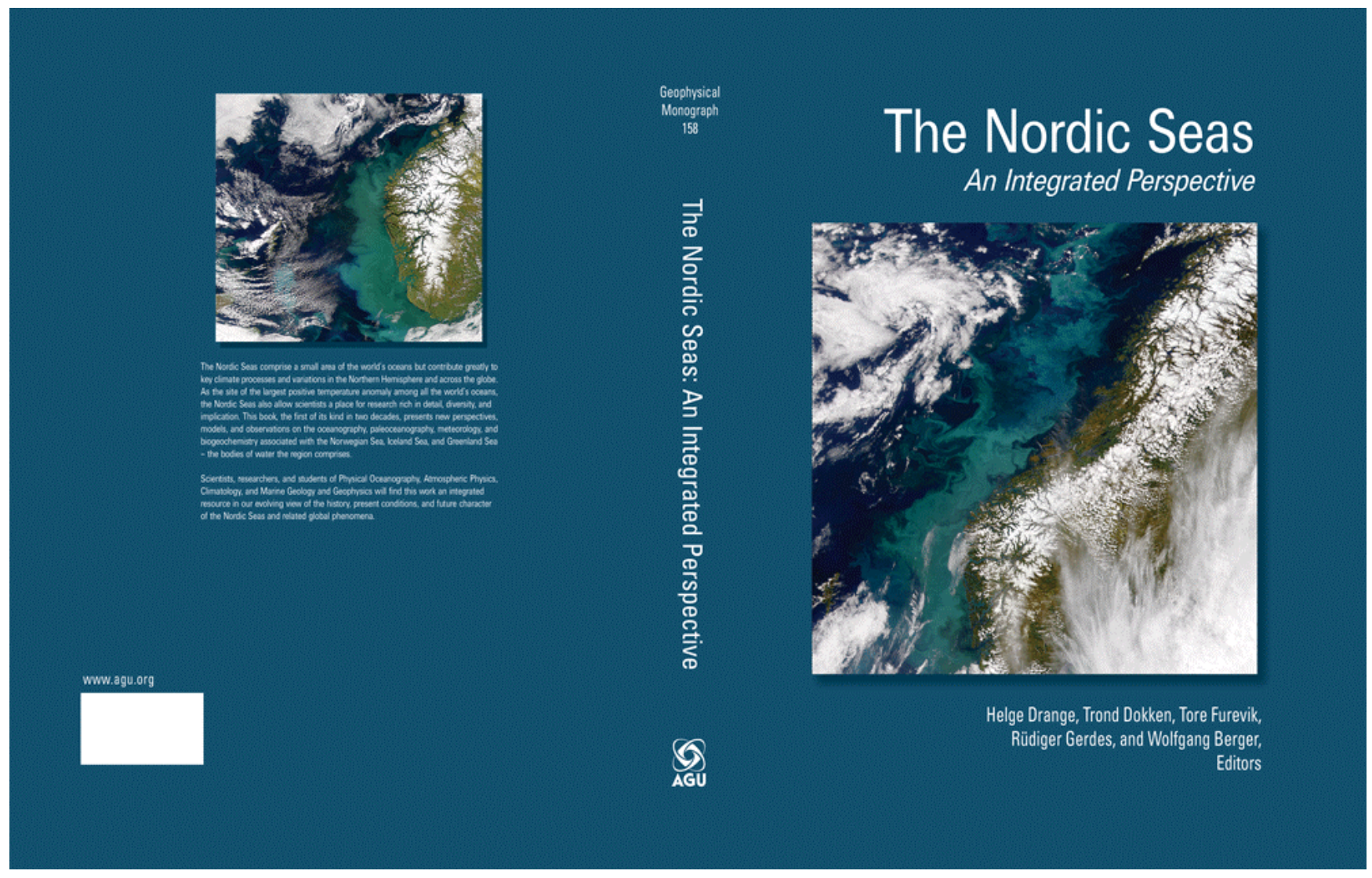


Drange, Gerdes, Gao, Karcher, Kauker, and Bentsen (2005): Ocean General Circulation Modelling of the Nordic Seas, in The Nordic Seas: An Integrated Perspective (Drange, Dokken, Furevik, Gerdes and Berger, Eds.), AGU Monograph 158, American Geophysical Union, Washington DC, pp. 199-220. Official version available from $\underline{\mathbf{A G U}}$.

\title{
OCEAN GENERAL CIRCULATION MODELLING OF THE NORDIC SEAS
}

\author{
Helge Drange $^{1-4}$, Rüdiger Gerdes 5 , Yongqi Gao ${ }^{1,2,4}$, Michael Karcher ${ }^{5,6}$, Frank Kauker, ${ }^{5,6}$, Mats Bentsen ${ }^{1,2}$ \\ ${ }^{1}$ Nansen Environmental and Remote Sensing Center, Bergen, Norway \\ ${ }^{2}$ Bjerknes Centre for Climate Research, University of Bergen, Bergen, Norway \\ ${ }^{3}$ Geophysical Institute, University of Bergen, Bergen, Norway \\ ${ }^{4}$ Nansen-Zhu International Research Centre, Beijing, China \\ ${ }^{5}$ Alfred Wegener Institute for Polar and Marine Research, Bremerhaven, Germany \\ ${ }^{6}$ O.A.Sys, Ocean Atmosphere Systems GbR, Hamburg, Germany
}

The complexity of the state-of-the-art Ocean General Circulation Models (OGCMs) has increased and the quality of the model systems has improved considerably over the last decades. The improvement is caused by a variety of factors ranging from improved representation of key physical and dynamical processes, parallel development of at least three classes of OGCM systems, accurate and cost-effective numerical schemes, an unprecedented increase in computational resources, and the availability of synoptic, multi-decadal atmospheric forcing fields. The implications of these improvements are that the current generation of OGCMs can, for the first time, complement available ocean observations and be used to guide forthcoming ocean observation strategies. OGCMs are also extensively used as laboratories for assessing cause-relationships for observed changes in the marine climate system, and to assess how the ocean system may change in response to, for instance, anomalous air-sea fluxes of heat, fresh water and momentum. The Nordic Seas are a particularly challenging region for OGCMs. The challenge is caused by characteristic length scales of only a few to about ten km, a variety of complex and interrelated ocean processes, and extreme air-sea fluxes. In the paper, an overview of the status of the prognostic modelling of the Nordic Seas marine climate system is given. To exemplify the status, output from two widely different, state-of-the-art OGCM systems are used. The paper also addresses processes that are still inadequately described in the current generation of OGCMs, providing guidelines for the future development of model systems particularly tailored for the Nordic Seas region.

\section{INTRODUCTION}

Numerical modelling of the climate of the Nordic Seas and the adjacent waters is an important method to assess and predict the influence of the region on the Atlantic Meridional Overturning Circulation (AMOC), the cycling of fresh water, and the ocean productivity. The field has made considerable progress in recent years due to a larger number of contributing modelling groups, the introduction of higher spatial resolution, and improved representation of important processes. Increasingly realistic atmospheric forcing data have been employed although their reliability in the Nordic Seas has still to be assessed. The combination of realistic forcing and the existence of high-quality in situ observations and continuous time series at key locations of the oceanic circulation have lead to validated models. Still, many problems remain, caused by the complexity of the topography, the small and short spatial and temporal scales of the main processes in the region, and the inherent coupling between the Nordic Seas and the entire Atlantic and Arctic Oceans. As in all high latitude oceans, baroclinic adjustment processes mediated by baroclinic Rossby waves are very slow. This has consequences for the ocean circulation response to atmospheric variability on time scales from seasonal to interannual. The response is more barotropic and more guided by topography than in mid-latitude oceans.

Numerical ocean-sea ice models address a broad range of scientific questions regarding the development of the circulation and water mass distribution in the Nordic Seas. They aid the interpretation of observations that are by their nature sparse in space and time [e.g. Hatun et al., this issue]. Usually, results of hindcast calculations are used for this purpose where a realistic time history of atmospheric forcing data is prescribed. This approach can, in principle, be used to assess the characteristics of decadal variability modes compared to e.g. greenhouse gas forced trends. Available atmospheric forcing fields cover the period since 1948 [e.g., Kalnay et al., 1996], meaning that the hindcast approach is currently somewhat restricted to decadalscale studies. 
Drange, Gerdes, Gao, Karcher, Kauker, and Bentsen (2005): Ocean General Circulation Modelling of the Nordic Seas, in The Nordic Seas: An Integrated Perspective (Drange, Dokken, Furevik, Gerdes and Berger, Eds.), AGU Monograph 158, American Geophysical Union, Washington DC, pp. 199-220.

Combined with observational data, models can provide a detailed state description of the system and its temporal development. The state description is valuable in itself but can also be utilized to initialise coupled ocean-sea ice-atmosphere models. This approach is of key importance for conducting reliable seasonal to decadal climate predictions [e.g., Collins et al., 2005]. Another important branch of modelling is numerical experimentation that acts as a substitute for the physical experiments that are usually not feasible (nor desirable) with the climate system. Idealized experiments and scenario calculations belong to this category.

No dedicated review exists on the sea ice-ocean modelling of the Nordic Seas. However, a description of mesoscale sea ice-ocean models and sea ice-ocean process studies in general is covered by Häkkinen [1991], whereas Hopkins [1991], Stevens [1991] and Heburn et al. [1995] introduced and reviewed relevant modelling of the Nordic Seas until the mid 1990's. The most relevant model review is by Mellor and Häkkinen [1994], addressing the development of coupled iceocean models with particular focus on the Arctic Ocean.

To limit and focus the scope of the paper, this review is heavily based on the output from two state-of-the-art OGCMs, both of which are driven by realistic, daily atmospheric forcing fields for the period 1948-2002. The objectives are to explicitly illustrate similarities and differences between the two models, to address the degree of realism in the simulated fields based on comparison with observations, and by that to demonstrate strengths and weaknesses of the present generation of OGCMs applied to the Nordic Seas region. In this respect the paper is more than a review as it presents the first multi-model comparison for the Nordic Seas.

The two model systems used differ substantially by construction: The Alfred-Wegner Institute North Atlantic/Arctic Ocean-Sea-Ice-Model (NAOSIM) uses levels of fixed depth as the vertical co-ordinate and is as such a representative of the classical family of OGCMs, whereas the Nansen Center model, which is a derivative of the Miami Isopycnic Coordinate Ocean Model (MICOM), uses surfaces of constant density as the vertical co-ordinate. Also the applied model domain, the spin-up procedure, the horizontal and vertical grid resolution, the details of the atmosphere forcing, the mixed layer dynamics, and several of the model parameterisations differ, implying that the presented results should not be interpreted as the output from a planned model intercomparison project.

The review starts with a brief overview of the available model systems and gives some examples of how the various model systems have been used to study the marine climate system of the Nordic Seas. In Section 3, a comparison between MICOM and NAOSIM are presented. For this comparison, the mean state and the variability of the volume fluxes into and out of the Nordic Seas, the horizontal circulation pattern, the seasonal sea surface salinity (SSS) and temperature (SST) fields, and the thickness of the upper mixed layer and the sea ice extent are considered. Comparisons are also made to observed values of several of these quantities. The review continues with a discussion of the particular challenges for the ocean modelling of the Nordic Seas (Section 4), and is ended by discussion and conclusion sections.

\section{PROGNOSTIC OCEAN MODELLING}

Numerical ocean model systems can in general be grouped into three main categories; diagnostic, prognostic and data-assimilation systems. In diagnostic modelling, the state of the ocean is directly derived from observations [e.g. Engedahl et al., 1988]. In prognostic modelling, which is the topic of this review, the evolution of the model system is governed by time and space dependent continuity and momentum equations, and an equation of state (see below), and prescribed atmospheric forcing fields. Data assimilation systems are built in response to the fact that both observations and prognostic model systems are imperfect: The dataassimilation system therefore feeds available observations into the prognostic model so that the model state remains close to the observed state throughout the integration [e.g. Bennett, 1992; Evensen, 2003; Stammer et al., 2003a,b]. For climate research, data-assimilation systems are of fundamental importance to seasonal to decadal climate prediction assessments as the initial state is of key importance for the evolution of the climate system [e.g., Collins et al., 2005].

Prognostic model systems are fully governed by the primitive equations [e.g., Müller and Willebrand, 1989] comprised of coupled time and space dependent momentum and continuity equations and an equation of state. The primitive equations are regarded as good approximations provided that vertical motion is much smaller than horizontal motion, and that the fluid layer depth is small compared to the radius of the sphere. Once the prognostic model is started from an initial state, it will compute, time-step by time-step and gridpoint by grid-point, a complete set of internally consistent dynamic and thermodynamic fields. The airsea boundary conditions are prescribed fields of wind stress, heat and fresh water fluxes. These fields represent the atmospheric forcing of the ocean-sea ice system. The most common atmospheric forcing products are monthly mean climatological fields, and daily varying fields available from, for instance, the NCAR/NCEP (http://www.cdc.noaa.gov/cdc/reanalysis/) and ECMWF 
Drange, Gerdes, Gao, Karcher, Kauker, and Bentsen (2005): Ocean General Circulation Modelling of the Nordic Seas, in The Nordic Seas: An Integrated Perspective (Drange, Dokken, Furevik, Gerdes and Berger, Eds.), AGU Monograph 158, American Geophysical Union, Washington DC, pp. 199-220.

(http://www.ecmwf.int/research/era/) reanalyses projects. By its nature, a prognostic model is the commonly used model system to study the dynamics of past, present and future atmosphere and ocean climate states.

Prognostic 3-dimensional ocean modelling extends back to the pioneering works of Bryan [1969] and Cox [1984]. This model system, now known as the Modular Ocean Model (MOM), was extended to the polar regions by Semtner [1976a,b]. The model system has continuously developed through improvements of the code, the physical parameterisations, and the numerics. The latest state of MOM is documented in Griffies et al. [2004]. The MOM system and derivations thereof is without comparison the most frequently and widely used OGCM system of today. NAOSIM is, as an example, a derivative of the MOM system.

The Bryan-Cox (or MOM) model system is also known as a level or geopotential co-ordinate OGCM as the vertical discretisation is based on layers at fixed depths. There are two alternative formulations for the vertical discretisation in OGCMs: One approach is to let the vertical co-ordinate follow topography, and this system is known as terrain-following (or sigma) coordinate OGCM. The Princeton Ocean Model (POM) developed by Blumberg and Mellor [1987] was the first of these models. A derivative of this system has been applied to the North Atlantic, the Nordic Seas and the Arctic by, in particular, Sirpa Häkkinen [Häkkinen and Mellor, 1992; Häkkinen, 1995, 1999, 2002; Mauritzen and Häkkinen, 1999].

A third approach is to treat surfaces of constant potential density, or isopycnals, as the vertical coordinate. Such a model system is known as an isopycnic co-ordinate OGCM. The motivation behind the latter choice of vertical discretisation is that the ocean transport and mixing are mainly directed along surfaces of constant density. The OPYC model developed by Oberhuber [1993] played a pioneering role in the use of isopycnal models for high latitude oceans. For instance, Aukrust and Oberhuber [1995] used an Atlantic-Arctic configuration with a grid focussed in the Nordic Seas while Holland et al. [1996] and Karcher and Oberhuber [2002] applied OPYC to study the mixed layer circulation and the exchanges of different water masses between the Arctic and the subarctic seas, respectively. Today, however, MICOM [Bleck et al., 1992] is the only widely used isopycnic co-ordinate model system. The NERSC model used in this review is a derivative of MICOM.

The geopotential, the terrain-following and the isopycnic co-ordinate OGCMs have all inherent advantages and weaknesses. As a consequence of this, hybrid co-ordinate OGCMs have been developed. The most well-known hybrid OGCM is the HYbrid Co- ordinate Ocean Model (HYCOM; Bleck [2002]) in which the open stratified ocean is treated with isopycnic co-ordinates, the shallow coastal regions are treated with terrain-following co-ordinates, and the upper mixed layer is treated with geopotential co-ordinates. In the limit of infinite numerical resources - and hence infinite grid resolution - the basic features of the various OGCM concepts will converge into one consistent model system [Semtner, 1995].

For a thorough review of prognostic ocean modelling in general, see Griffies et al. [2000]. Of high relevance are also the results of several model intercomparison projects. One such project for the North Atlantic that includes geopotential, terrain-following and isopycnic co-ordinate OGCMs is documented by DYNAMO Group [1997]; Böning et al. [2001]; New et al. [2001]; and Willebrand et al. [2001]. Another is the Arctic Ocean Model Intercomparison Project (AOMIP) with results presented in Proshutinsky et al. [2001], Steiner et al. [2004] and Uotila et al. [2005]. More information about AOMIP is available at http://fish.cims.nyu.edu/project_aomip/overview.html.

\section{MODEL-MODEL AND OBSERVATION-MODEL COMPARISONS}

This section is split into two parts: The first part addresses similarities and differences between the MICOM and NAOSIM systems. Such a comparison is useful as it points towards robust model responses (in the sense that the models respond similarly to the applied forcing, indicating that the model physics is adequately represented) and model uncertainties (indicating where the model systems need to improve). The second part contains a comparison between simulated and observed fields as this is the only way to assess the degree of realism of the models. Both modelmodel and observation-model analyses become quickly extensive [e.g., Karcher et al., 2003; Steiner et al., 2004; Hátún et al., this issue], so this review has been restricted to display and briefly discuss some of the key large-scale features of the Nordic Seas.

The fields to be addressed are: The annual mean circulation at $150 \mathrm{~m}$ depth, the annual mean barotropic (or vertically integrated) circulation, the long-term mean and temporal variability of the volume transport, the seasonal cycle of SST and SSS, and the mean, minimum, and maximum thickness of the mixed layer and sea ice concentration, both for March and September. Short descriptions of the two model systems are given in the appendix.

\subsection{Simulated circulation in the Nordic Seas region}


Drange, Gerdes, Gao, Karcher, Kauker, and Bentsen (2005): Ocean General Circulation Modelling of the Nordic Seas, in The Nordic Seas: An Integrated Perspective (Drange, Dokken, Furevik, Gerdes and Berger, Eds.), AGU Monograph 158, American Geophysical Union, Washington DC, pp. 199-220.

The most fundamental bulk properties of the marine climate system of the Nordic Seas are the volume, heat and salt fluxes into and out of the region. The pole-ward flow of Atlantic Water transports significant amounts of heat, salt, carbon and nutrients into the region and further into the Arctic Ocean [e.g., Hansen and Østerhus, 2000; Blindheim and Østerhus, this issue; Skjelvan et al., this issue], whereas the southward flowing cold and fresh Polar waters off the coast of Greenland, and the dense GSR overflow waters, are of key importance for the hydrographic, and likely the dynamic, state of the North Atlantic climate system [e.g., Dickson et al., 2002; Curry et al., 2003; Hansen et al., 2004].

Figure 1 shows the observed surface circulation from the 1990s based on analyses of drifter trajectories [Jakobsen et al., 2003] and the mean simulated circulation at $150 \mathrm{~m}$ depth for the period 1948-2002. The model systems show, in accordance with the drifters, that the inflow of Atlantic Water to the Nordic Seas takes place just east of Iceland, southeast of the Faroes, and along the Scotish slope, with a minor inflow component located on the eastern side of the Denmark Strait (the Irminger Current). Furthermore, the Atlantic Water crossing the Iceland-Scotland Ridge flows into the North Sea and continues close to the coast of Norway or in an outer branch following the outer Norwegian continental slope. At about $70^{\circ} \mathrm{N}$, the Atlantic Water splits into two branches, one meandering into the Barents Sea close to Northern Norway, another branch heading towards the Fram Strait. The simulated circulation fields show a general agreement with the drifter field for all of these features.

However, the circulation pattern in the Fram Strait region differs between the models, with NAOSIM closest to the drifter data. NAOSIM produces a twocurrent system with northward flowing water on the Spitzbergen side and southward flowing water on the Greenland side of the strait, whereas almost all the northward flowing water apparently recirculates in the strait in MICOM. Further south, the Polar Water follows the coast of Greenland towards the Denmark Strait. One branch of the Polar Water continues through the Denmark Strait, whereas the other branch flows eastward north of Iceland as the East Icelandic Current (EIC). The EIC is also fed by the northward flowing Irminger Current.Both models simulate the twodirectional flow in the Denmark Strait. In the Nordic Seas interior, both models fail to simulate the topographically steered, north-westward directed, flow structure seen in the central basin in the drifter data. The reason for this failure is not known, but it could be linked to a too smooth topography in the models. The internal circulation is rather similar between the models but with NAOSIM showing sharper gradients and more details. A profound difference, however, is the location of the Greenland Gyre which is more to the west in NAOSIM. It will be shown in Section 3.5 that the central Greenland Sea gyre is too intensive and is located slightly too far to the west in NAOSIM, and that it is too diffusive and is located too far to the east in MICOM. The latter difference also implies that NAOSIM produces a more prominent eastward-directed current north of Jan Mayen.

It is apparent from this and the following figure that NAOSIM produces stronger gradients and more details than MICOM. This is likely caused by the essentially doubled horizontal resolution in NAOSIM (28 km vs. 40 $\mathrm{km})$, but can also be attributed to the quite different characteristics of the winter-time mixing in the region and the somewhat different extent of sea ice (see Section 3.5).

Figure 2 shows the barotropic (or vertically integrated) flow field. Many of the features from the flow at $150 \mathrm{~m}$ are present in the barotopic field, indicating the weak stratification and the importance of the topography (see Fig. 1 in Blindheim and Østerhus [this issue]) in guiding the circulation, including the surface flow, in the region. The controlling role of topography on the surface circulation has been known for a long time, but was first demonstrated in OGCMs by Legutke [1991], and later confirmed by Aukrust and Oberhuber [1995].

\subsection{Simulated and observed volume fluxes in the Nordic Seas region}

More quantitative results are obtained by examining the volume transports into and out of the region, i.e., the northward, southward and net flow through the Denmark Strait, across the Iceland-Faroe Ridge, between the Faroe Islands and Scotland, through the Barents Opening and through the Fram Strait. In addition, there is a small component of flow through the English Channel.

There are numerous observation-based estimates of the volume, heat and fresh water transports through the Nordic Seas. Unfortunately, some of the estimates vary by a factor two to three [e.g., Simonsen and Haugan 1996; Hansen and Østerhus 2000; Blindhein and Østerhus, this issue]. Accurate current meter observations are only available from around 1994 [Østerhus et al., 2005]. We therefore split the discussion into two parts; the full integration period 1948 to present, essentially without reliable observational guidelines, and the period from 1994 with direct current meter observations.

We are aware, however, that even with accurate current meter observations, the derivation of volume, heat and salt fluxes is far from solved. Lateral 
Drange, Gerdes, Gao, Karcher, Kauker, and Bentsen (2005): Ocean General Circulation Modelling of the Nordic Seas, in The Nordic Seas: An Integrated Perspective (Drange, Dokken, Furevik, Gerdes and Berger, Eds.), AGU Monograph 158, American Geophysical Union, Washington DC, pp. 199-220. Official version available from $\underline{\mathbf{A G U}}$.

movements of strong fronts, eddy activity and spatial gaps in the coverage (e.g. due to instrument loss or failure) often hamper a reliable estimate of these fluxes. This has recently been discussed by Schauer et al. [2004] for flux estimates from observations in the Fram Strait. They estimate the error as being of the order of the net volume fluxes through the strait. The fact that the fluxes are variable in time and that usually there is no synoptic cover of all straits with observations also eliminates the closure of missing information from one strait with observations from the others.

\subsubsection{Mean volume transports 1948-2002}

The simulated net volume transports into and out of the Nordic Seas for the period 1948-2002 are provided in Fig. 3. It follows that the total amount of water flowing northward across GSR is $9.3 \mathrm{~Sv}$ in NAOSIM and 9.2 Sv in MICOM, whereas the corresponding fluxes into the Arctic Ocean are $5.9 \mathrm{~Sv}$ and $7.9 \mathrm{~Sv}$, respectively. For the net southward flow, the numbers are $9.5 \mathrm{~Sv}$ (NAOSIM) and $8.6 \mathrm{~Sv}$ (MICOM) across GSR, and 5.8 Sv (NAOSIM) and 7.3 Sv (MICOM) for the two Arctic sections. The flow through the English Channel is small and is about $0.1 \mathrm{~Sv}$ in the two models.

The above volume fluxes, and even more the individual fluxes for the sections in Fig. 3 and Table 1, show some differences between the two model systems. There are several reasons for these differences. First of all, the version of MICOM used in this review is global in extent, meaning that any residual flow of water through the Nordic Seas region, averaged for a month or longer, is balanced by volume transports through the Bering Strait and the Canadian Archipelago. In MICOM, there is a net northward flow of $0.6 \mathrm{~Sv}$ through the Nordic Seas (Fig. 3 and Table 1). This residual is balanced by a pole-ward flow of $1.0 \mathrm{~Sv}$ through the Bering Strait and a net southward flow of 1.6 Sv through the Canadian Archipelago. There is near zero residual flow through the Nordic Seas in NAOSIM, with a corresponding near zero net flow through the Canadian Archipelago due to the closed Bering Strait. Therefore, volume transport differences of about $0.5 \mathrm{~Sv}$ can be expected between the two model systems, at least for some of the transport routes.

Secondly, even OGCMs that are forced - and by that to quite a degree constrained - by prescribed atmospheric momentum, heat and fresh water fluxes, as is the case for MICOM and NAOSIM, have a certain degree of internal variability. This internal variability originates from the essentially unknown ocean initial state. Differences in the initial ocean state, particularly hydrographic differences in the weakly stratified regions in the Nordic Seas and in the North Atlantic sub-polar gyre and the flux of fresh water through the Fram Strait, have the potential to moderate the ocean circulation in the region on time scales from years to decades [e.g., Haak et al., 2003; Bentsen et al., 2004].

Repeated model simulations with identical model systems but with different ocean initial states indicate that the major volume fluxes in the Nordic Seas may differ with a few tenths of Sv to about $0.5 \mathrm{~Sv}$. This is illustrated in Fig. 4, showing the net volume transports given by MICOM for an integration continuing from the ocean state at the end of the MICOM realisation shown in Figs. 1-3. Significant differences may be noticed, e.g in the Fram Strait where the long-term mean northward flow in the second integration is reduced from 3.8 to 3.2 $\mathrm{Sv}$, and the southward flow from 5.3 to $4.4 \mathrm{~Sv}$. The second MICOM integration (MICOM*) is only included here for illustrating the effect different ocean initial states may have on the simulated ocean climate, and will not be used further.

To sum up: The combined effect of regional versus global model domain, and internal variability of any OGCM system based on the essentially un-known ocean initial state, may produce volume transport differences of about $0.5 \mathrm{~Sv}$ (this figure is based on the presented comparison between the NAOSIM, MICOM and MICOM* realisations, and may be larger if more model systems or realisations are included in the analyses). Consequently, volume transport differences exceeding, say $1 \mathrm{~Sv}$, cannot be simply explained by differences in the model domain (i.e., global versus regional domains) or the un-known ocean initial state. In this case model differences can only be attributed to the intrinsic properties of the models like horizontal and vertical model resolution, formulation and parameterisation of resolved and un-resolved ocean processes, and the numerical implementation of the governing equations.

\subsection{Comparison between observed and simulated mean volume transports}

The simulated volume transports in Fig. 3 can be compared with available observation-based transport estimates. As already mentioned, reliable velocity measurements are only available from 1994 onwards. A compilation of available literature values, together with simulated values for the same time period as for the observations, is presented in Table 2. For the period October 1994 to August 2000, the observation-based estimate of the northward flow of Atlantic Water in the Denmark Strait is $0.75 \mathrm{~Sv}$ in Østerhus et al. [2005]. The respective MICOM value is $0.8 \mathrm{~Sv}$, whereas that of NAOSIM is higher with $1.9 \mathrm{~Sv}$. For the Faroe-Scotland openings, both MICOM and NAOSIM are close to the observed transports, but with the MICOM transport across the Iceland-Faroe Ridge and the NAOSIM transport across the Faroe-Scotland opening $0.8 \mathrm{~Sv}$ too 
Drange, Gerdes, Gao, Karcher, Kauker, and Bentsen (2005): Ocean General Circulation Modelling of the Nordic Seas, in The Nordic Seas: An Integrated Perspective (Drange, Dokken, Furevik, Gerdes and Berger, Eds.), AGU Monograph 158, American Geophysical Union, Washington DC, pp. 199-220.

high. We may note, however, that the estimates for the Atlantic Water inflow across the Iceland-Faroe ridge range from 3.3 Sv [Hansen and Østerhus, 2000] to 3.8 Sv [Østerhus et al., 2005] depending on the method and the time interval.

A striking difference between the two models is apparent in the southward transports through Denmark Strait with 7.5 Sv for NAOSIM and 4.0 Sv for MICOM. This is partly balanced by the southward flow across the Iceland-Scotland ridges of 2.2 Sv for NAOSIM in contrast to $5.0 \mathrm{~Sv}$ for MICOM. Observationally based estimates for the mostly deep southward flows across the Iceland-Scotland ridges are 2.2-2.9 Sv with large uncertainties [Hansen and Østerhus, 2000]. For Denmark Strait an observationally based estimate of 3 Sv of deep overflow to the south is rather well accepted [Blindheim and Østerhus, this issue], while the shallow outflow with the EGC is very uncertain. Hansen and Østerhus [2000] calculated the combined outflow at the surface through Denmark Strait and the Canadian Archipelago to be $3 \mathrm{~Sv}$, based on the residual from estimates for all other flows in and out of the Nordic Seas.

For the Barents Sea Opening, most recent estimates are based on current meter observations from the major inflow section between Bear Island and Norway from 1997 to 2001. Ingvaldsen et al. [2004] calculated from these observations 1.5 Sv for the inflowing Atlantic Water adding up with 0.5-1 Sv for the Norwegian Coastal Current to a total of 2-2.5 Sv. This compares with an inflow of 2.7 Sv for NAOSIM and 4.2 Sv for MICOM in the 1995-2000 period. For the Fram Strait, flow estimates are uncertain because of the very strong recirculation in the strait.

When evaluating the differences of model and observationally based estimates we have to consider that several of the water masses which pass the Nordic Sea openings are subject to intense recirculation at the openings which complicates the interpretation of the transports at fixed sections: this hold especially for the Fram Strait, Denmark Strait and the Faroer-Scotland gap. Also the fact that different observational estimates are based on different definitions for the passing water masses may lead to confusion. Here we use vertically integrated total water column transports for the models without perfoming a detailed comparison along the various water mass definitions. A discussion about these complications can be found in e.g. Nilsen et al. [2003].

In conclusion, an encouraging correspondence between the observed and simulated volume transports are obtained, particularly for the inflow of Atlantic Water between Iceland and Scotland. Also the simulated heat transports (Table 2) are consistent with the observation-based values.

\subsection{Model-model comparison of the interannual variability of the volume transports}

The major variability modes of the Nordic Seas marine climate system can be explored by examining the variability of the amount and properties of water flowing into and out of the region. Irrespective of the actual match or mismatch between the simulated mean transports through the different sections shown in Fig. 3, one would expect that the simulated flow anomalies should show similarities over the integration period. The correspondence should be particularly clear for quantities that are directly and to a large degree driven by the applied atmospheric forcing fields, or for processes that are properly resolved by the models. Or conversely, it is likely that simulated quantities that show a high degree of co-variance over time are forced, in a direct way, by the applied atmospheric fields, and that the governing ocean dynamics is appropriate.

Figure 5 shows the simulated northward and southward volume transport anomalies for both model systems for the five open ocean sections in Fig. 3. In the figure caption, the linear correlation of the transport anomalies between MICOM and NAOSIM are given. It follows from Fig. 5 that the variability in the northward flow across the Denmark Strait is weak (standard deviation of $0.16 \mathrm{~Sv}$ and $0.13 \mathrm{~Sv}$ for MICOM and NAOSIM, respectively), and that there are no correlation between the two simulated time series. The situation is opposite for the northward flow anomalies between Iceland and Scotland and across the Barents Opening. Here the mean standard deviations of the two models are $0.37 \mathrm{~Sv}$ (Iceland-Faroe), $0.45 \mathrm{~Sv}$ (IcelandScotland) and 0.33 Sv (Barents opening), and the given correlations are significant. It is interesting, and a positive result, that two widely different model systems produce so consistent flow anomalies through these three sections for such a long time period. It should be noted that the correlation between the two model systems breaks down for the Fram Strait, which may not be too surprising given the differences in the circulation in the region (cfr. Figs. 1-2).

The southward volume transport anomalies are given in the right panels of Fig. 5. The two model systems produce quite consistent transport anomalies in the Denmark Strait, across the Iceland-Faroe Ridge, between the Faroes and Scotland and through the Barents Opening, but not for the Fram Strait.

In general, the magnitude of the volume transport anomalies is comparable between the two model systems, although MICOM tends to produce slightly larger anomalies than NAOSIM.

The extent to which the temporal evolution of the simulated anomalies in Fig. 5 is realistic can only be assessed based on comparison with continuous and high- 
Drange, Gerdes, Gao, Karcher, Kauker, and Bentsen (2005): Ocean General Circulation Modelling of the Nordic Seas, in The Nordic Seas: An Integrated Perspective (Drange, Dokken, Furevik, Gerdes and Berger, Eds.), AGU Monograph 158, American Geophysical Union, Washington DC, pp. 199-220. Official version available from $\underline{\mathbf{A G U}}$.

quality current meter observations (cfr. the discussion in Sec. 3.2). Here, as an example, observed and simulated transports are compared for the northward flow in the Faroe-Shetland Channel for the period October 1998 to December 2002 (Fig. 6). Consistent with Table 2, both MICOM and NAOSIM are, on average, close to the observed northward volume flux. The monthly mean variability is, however, larger in the observation-based time series. By subtracting the mean values of the time series and by normalising the resulting anomalies, a close match is obtained. This finding illustrates the potential for combining observations and prognostic model systems to better understand the variability modes of the marine climate system in the region, and that available model systems have the potential to be used to extend, in time and space, available observations (see e.g. Hátún et al. [this issue]).

\subsection{Simulated thermodynamic surface properties}

In the following, a model-model comparison addresses the thermodynamic properties of the Nordic Seas. We start with SSS or equivalently the upper ocean fresh water content. Away from the ice edge where strong salt fluxes might occur, SSS is far less influenced by the atmospheric forcing than SST. Therefore, salinity can be considered as a tracer for the transport and mixing of the major water masses in the region.

The upper panels in Fig. 7 displays the March distribution of SSS in MICOM and NAOSIM. Due to the differences in resolution, NAOSIM describes more details and accepts sharper gradients than MICOM. This is especially pronounced in the EGC that is visible as a fresh and cold boundary layer all the way to the southern tip of Greenland in NAOSIM while MICOM produces a front between the polar waters of the EGC and the subpolar Atlantic water aligned with the GreenlandIceland Ridge. The northward flowing Atlantic Water is evident off the coast of Norway. NAOSIM is fresher than MICOM in the central and eastern part of the Nordic Seas.

The March SST is quite similar between the two models in the east (lower panels in Fig. 7), but with lower surface temperatures in MICOM in the central part of the Nordic Seas, and with a very cold region in the central Greenland Sea in NAOSIM.

Observed and simulated vertical distributions of temperature in July 1999 along $75^{\circ} \mathrm{N}$, and thus crossing the central Greenland Sea basin, are provided in Fig. 8. The observations clearly show the warm poleward flowing Atlantic Water towards east, extending below $500 \mathrm{~m}$ eastward of $9^{\circ} \mathrm{E}$. At the surface, waters exceeding $6^{\circ} \mathrm{C}$ are found in the upper $50 \mathrm{~m}$ eastward of about $3^{\circ} \mathrm{E}$. In the central Greenland Basin near the prime meridian, temperatures below $0{ }^{\circ} \mathrm{C}$ is found below about $50 \mathrm{~m}$. In the west, the return Atlantic Water flows along the
Greenland continental slope, whereas cold Polar Water constitutes the main water mass on the Greenland shelf.

Both the poleward flowing Atlantic Water and the return Atlantic Water are clearly seen in the simulations. The poleward flowing Atlantic Water is, however, too narrow in both models, and then particularly in MICOM. The mixed layer temperature in MICOM is close to the observed temperature, whereas NAOSIM has a too warm layer at the surface. Towards west, NAOSIM produces too strong and prominent return Atlantic Water. Both models capture the cold Polar Water on the Greenland shelf. It is encouraging, despite the mentioned differences, that both model systems are able to produce realistic sub-surface temperature distributions after a total integration time of about 100 years (spin-up plus the reanalysis integration, see appendix).

Figure 9 displays the simulated mean and extreme sea ice concentrations for the period 1948-2002. The corresponding observed sea ice edge position is given for the period 1978-2002. The Is Odden - the sea ice structure extending into the Greenland Sea in the upper left panel of Fig. 9 - is very pronounced in NAOSIM as documented in the mean sea ice concentration over the integration period. Sea ice formation and transport in the Is Odden are important processes for deep convection in NAOSIM [Gerdes et al., this volume]. The NAOSIM maximum sea ice extent seems to even exceed the observed sea ice extent in the extremely cold year of 1881 [Blindheim and Østerhus, this issue]. It should be kept in mind, however, that the ice extent extrema of Fig. 9 are derived from time series at individual grid points throughout the integration period 1948-2002, and that the map does not correspond to a state the model has actually occupied during the integration. For instance, high sea ice cover in the Barents Sea and in the Greenland Sea virtually never occur simultaneously. A detailed comparison of observed sea ice variability with that simulated by NAOSIM is given in Kauker et al. [2003].

The combination of winter SSS and SST governs the thickness of the upper well-mixed layer in the ocean. MICOM and NAOSIM treat the mixed layer differently, with an explicit mixed-layer model in MICOM based on the Gaspar [1988] bulk representation, whereas NAOSIM does not employ an explicit mixed layer parameterisation. A deep winter mixed layer is a result of convective mixing as a result of unstable stratification. For the diagnostic, the mixed layer thickness in NAOSIM is based on the depth where the density is $0.02 \mathrm{~kg} \mathrm{~m}^{-3}$ higher than the surface density. It is therefore difficult to perform a one-to-one comparison of the two mixed layer fields. Nevertheless, the structure of deep mixing in March is quite similar with rather deep mixing south of GSR, along the path of the 
Drange, Gerdes, Gao, Karcher, Kauker, and Bentsen (2005): Ocean General Circulation Modelling of the Nordic Seas, in The Nordic Seas: An Integrated Perspective (Drange, Dokken, Furevik, Gerdes and Berger, Eds.), AGU Monograph 158, American Geophysical Union, Washington DC, pp. 199-220. Official version available from $\underline{\mathbf{A G U}}$.

Atlantic Water in the eastern parts of the Nordic Seas, and within the Greenland Basin. The history of deep convection in the Nordic Seas and the Labrador Sea as simulated in NAOSIM is the topic of Gerdes et al. [this volume].

There are substantial differences between the two model systems when interannual variability of convective winter mixing is considered, see Fig. 10. Under minimum mixing conditions, NAOSIM produces very shallow convection that is restricted to the NwAC while MICOM shows shallow convection over large parts of the Nordic Seas and maintains relatively deep convection in the Irminger Basin and south of Iceland (not shown). NAOSIM convective mixing depth strongly exceeds the mixing depth in MICOM at maximum mixing in the Greenland Sea (lower panels in Fig. 10). In fact, NAOSIM mixes to the sea floor in the Greenland Sea at maximum mixing, whereas MICOM produces less deep but a much more extended and uniform mixing along the eastern and northern rims of the Nordic Seas. A likely reason for this difference is caused by the very weak stratification in NAOSIM compared to MICOM (Fig. 8). Dedicated model experiments incorporating passive tracers like chlorofluorocarbons [Schlosser et al., 1991; Bönisch et al., 1997] or sulphur hexafluoride [Watson et al. 1999; Olsson et al., 2005; Eldevik et al., this isse] are probably required to properly address the mean state and the variability of the simulated mixed layer.

\section{PARTICULAR CHALLENGES FOR THE MODELLING OF THE NORDIC SEAS}

\subsection{Model specific challenges}

In the previous section, particular focus was put on the exchanges of the Nordic Seas with the adjacent ocean basins. We regard proper representation of these exchanges as the foremost challenge for modelling the Nordic Seas as a key region of the global ocean circulation. This is particularly the case since processes within the Nordic Seas influence the exchange rates and the properties of the waters exported to the Atlantic and Arctic oceans.

For both the exchanges and the interior processes, proper resolution of the ocean eddies, or the baroclinic Rossby Radius, of $O(10 \mathrm{~km})$ is important. As a rule of thumb; an OGCM will properly describe ocean dynamics on a horizontal scale of about 5 times the grid spacing. Proper model representation of the deformation radius would therefore require an ocean grid spacing of 1-2 km. Such a fine grid mesh for the Nordic Seas and parts of the neighbouring oceans is currently on the limit of what is computationally feasible, and certainly beyond the computational resources available for most ocean modelling groups. Models with insufficient resolution - like virtually all of the current ocean components of coupled climate models - typically misrepresent the properties of the deep overflows that form the dense constituents of NADW. This can result in the subpolar North Atlantic becoming the main source for northern hemisphere dense water in the models. It has been demonstrated [Döscher and Redler, 1997] that this can result in a false sensitivity of the models to fluctuations in atmospheric forcing and anomalous fresh water influx to the North Atlantic. The deep convection in the Labrador Sea is much more susceptible to anomalies than the more robust formation of intermediate waters north of GSR occurring over long distances and through several processes. Furthermore, the potentially important process of energy transfer from the large-scale potential energy reservoir to the kinetic energy of the large circulation is not captured by the present parameterizations.

Enhanced grid resolution can be obtained by nesting of regional, high-resolution models into larger, coarser resolution models. One variant of this approach are regional models that receive boundary conditions from climatology [e.g., Gerdes et al., this issue] or larger scale models [e.g., Hátún et al., this issue] without feeding back into these 'parent' models. Regional OGCMs have the advantage that the spatial grid mesh can be fine, possibly resolving the first baroclinic radius of deformation. The disadvantage with regional model systems is that water mass fluxes and their properties (i.e., temperature, salinity and tracer concentrations) have, in general, to be prescribed at the lateral boundaries. Technical problems can lead to boundary artefacts propagating into the model domain. For more information about open boundary conditions and nesting of model systems with different resolution, see Martinsen and Engedahl [1987]; Ginis et al. [1998]; Jensen [1998]; Palma and Matano [2000]; Perkins et al. [1997]; Heggelund and Berntsen [2002].

The overflow of dense water masses across the GSR is associated with excessive mixing in many ocean models [Gerdes, 1993; Roberts and Wood, 1997]. On the other hand, it has been a problem for isopycnal models to include sufficient entrainment of ambient fluid during the overflow [Roberts et al., 1996]. New parameterisations [Hallberg, 2000; Shi et al., 2001] have been developed and implemented to reduce this problem. However, according to Gerdes [1993], potential vorticity constraints make mixing or frictional modification of the flow inevitable in models that don't resolve the baroclinic Rossby Radius and when the overflowing water masses experience large changes in layer thickness.

Bottom boundary layer parameterisations in OGCMs are reviewed by Killworth [2003], and various schemes 
Drange, Gerdes, Gao, Karcher, Kauker, and Bentsen (2005): Ocean General Circulation Modelling of the Nordic Seas, in The Nordic Seas: An Integrated Perspective (Drange, Dokken, Furevik, Gerdes and Berger, Eds.), AGU Monograph 158, American Geophysical Union, Washington DC, pp. 199-220. Official version available from $\underline{\mathbf{A G U}}$.

have been devised, among others, by Beckmann and Döscher [1997] and Killworth and Edwards [1999]. These schemes provide a pathway for dense waters down the topographic slopes and avoid excessive entrainment. The schemes have been employed in many large-scale ocean models where they, to some degree, improve overflows and sloping convection from high latitude shelf seas. A new approach is due to Kösters et al. [2005] who introduce a parameterization based on hydraulic control theory to describe the strength of the Denmark Strait Overflow in a large-scale Atlantic model.

The overflows and other exchanges across the boundaries of the Nordic Seas are strongly linked by continuity. A weaker overflow will thus be associated with a weaker inflow of Atlantic waters. Weaker inflow of Atlantic waters will lead to reduced heat release from the ocean to the atmosphere in the Nordic Seas, in turn affecting the properties of the return Atlantic Water that is an important contribution to the overflows. The heat release can also affect Arctic sea ice volume [Goose et al., 2004], although this is an effect not included in ocean-sea ice models forced by prescribed atmospheric fields. More directly, the Atlantic inflow affects the heat supply to the Atlantic layer of the Arctic [Karcher et al., 2003; Gerdes et al., 2003] and the position of the sea ice edge in the Barents and Greenland seas [Kauker et al., 2003].

The branching of the Atlantic water into the two Arctic contributaries and the return Atlantic Water as well as the branching of the EGC into the Jan Mayen Current and the East Icelandic Current are heavily influenced by details of the topography. The bathymetry of an OGCM is usually computed as the mean value of the real ocean depth underlying each horizontal grid cell. This implies that bathymetric features like ridges and channels are smoothed. The degree of smoothing is therefore governed by the horizontal length-scale of the bathymetric features compared to the actual grid spacing. In addition, some OGCMs require a smoothed bathymetry to avoid numerical instabilities. This has particularly been the case for terrain-following OGCMs.

Smoothed (or artificially reduced) height of ridges is usually not adjusted in OGCMs, whereas deep channels are, at least in climate modelling, commonly adjusted by artificial widening or deepening of the channels [Biastoch et al., 2003; Beismann and Barnier, 2004]. Again, proper resolution of these features is one of the basic requirements for Nordic Seas circulation models. However, horizontal and vertical grid spacing have further, less obvious effects. The energy transfer between baroclinic and barotropic modes seems to be very sensitive to resolution as the much larger energy of barotropic flows in a higher resolution version of NAOSIM indicates [K. Fieg, pers. comm.]. Clearly, the representation of the Joint Effect of Baroclinicity and Relief (JEBAR) [Sarkisyan and Ivanov, 1971; Mertz and Wright, 1992] in a region of strong water mass boundaries and characterized by deep and narrow channels, steep slopes and complex ridges is a particular challenge for ocean modelling.

The central Greenland Sea is one of few locations where open ocean convective mixing takes place [Marshall and Schott, 1999]. The process is believed to influence the ventilation of dense, sub-surface water masses on climate time scales. Except for the large-scale downward vertical advection proposed by Budeus et al. [1998], most vertical mixing processes take place on scales which are not and can not in the foreseeable future be explicitly resolved by OGCMs. Several parametrisation schemes have therefore been proposed to include vertical sub-grid scale processes [Paluskiewicz and Romea, 1997; Canuto et al., 2004]. Much more work is, however, needed to properly incorporate a physically consistent description of smallscale vertical mixing processes in climate-type OGCMs. Linked to open ocean convection is also the treatment of brine waters generated during freezing of sea ice. Finescale modelling has been carried out to describe the dynamics of brine waters released from sea ice [Kämpf and Backhaus, 1999], but the incorporation of this effect in OGCMs is typically ignored or incorporated in a highly simplified way.

Finally, the Atlantic inflow into the Arctic is linked to the outflow of much fresher waters near the surface, feeding the EGC. The fresh water carried by the EGC can affect the interior of the Nordic Seas and especially the convection in the central Greenland Sea. Most of the fresh water, however, is carried through Denmark Strait into the subpolar Atlantic. Proper representation of both the subduction of the northward flowing saline Atlantic Water under the fresh polar water in the Fram Strait region, the dynamics of the fresh water along the coast of Greenland (and, similarly, along the coast of Norway), and the frontal mixing between the fresh water and the more saline open ocean surface waters are challenges for OGCMs.

\subsection{Observation-based evaluation of OGCMs}

The only way to proceed from plain comparison of model results and by that identifying model weaknesses and deficiencies are to actively include observations in the analyses. Figure 6, showing a one-to-one comparison between observed and simulated northward transport through the Faroe-Scotland Channel, provides an example of direct observation-based evaluation of OGCMs. Unfortunately, available observations of the marine climate system are, in general, scattered in time and space. It is therefore difficult, and in many cases 
Drange, Gerdes, Gao, Karcher, Kauker, and Bentsen (2005): Ocean General Circulation Modelling of the Nordic Seas, in The Nordic Seas: An Integrated Perspective (Drange, Dokken, Furevik, Gerdes and Berger, Eds.), AGU Monograph 158, American Geophysical Union, Washington DC, pp. 199-220. Official version available from $\underline{\mathbf{A G U}}$.

impossible, to adequately address the quality, or realism, of a model system on climate (i.e., multi-decadal) time scales, as on the time scale of Fig. 5. It should be mentioned, however, that the Nordic Seas is one of the regions in the World Ocean with best observational coverage [Blindheim and Østerhus, this issue; Furevik et $a l ., 2002]$. Acquisition, quality check and synthesis of available observations are therefore needed to generate the best possible observation-based background for evaluating the mean state and the variability of simulated ocean states. Needless to say, continuous observations of key ocean parameters at key ocean locations are of paramount importance for any evaluation of OGCMs.

For decadal and longer time scales, the use of tracers like chlorofluorocarbons (CFC-11 and CFC-12) and radiocarbon $\left({ }^{14} \mathrm{C}\right)$ has turned out to be useful and costeffective in assessing the integrated (or net) effect of ventilation of the basin-scale and World Ocean surface waters [e.g., Toggweiler et al., 1989; England and Maier-Reimer, 2001; Dutay et al., 2002; Gao et al. 2003]. Furthermore, tracers from point sources like radioisotopes from the European nuclear re-processing plants have been useful to address the inter-annual transport, mixing and age properties of, for instance, the Atlantic Water in the Nordic Seas region [Nies et al., 1998; Karcher et al., 2004; Gao et al., 2004, 2005]. On shorter time and smaller spatial scales, dedicated tracer experiments have been found to be of great use for assessing small-scale mixing and transport of explicitly tagged water masses. A unique example here is the deliberate release of sulphur hexafluoride in the central Greenland Sea in 1996 [Watson et al. 1999], and the subsequent observation of the spreading of the tracer within and out of the Nordic Seas [Olsson et al., 2005; Eldevik et al., this issue].

\section{CONCLUSION}

Numerical modelling of the ocean-sea ice system of the Nordic Seas and adjacent areas has reached a state of similar maturity to that of Atlantic and Arctic modelling efforts. This is the case despite some unique challenges that are posed by the small inherent scale of oceanic motion, the large water mass contrast between inflowing Atlantic and Arctic water masses, and the large influence of fresh water flux fluctuations. Particularly, it is demonstrated that the mean exchanges into and out of the Nordic Seas agree with available observed estimates, and that interannual variations do correlate with observations, although the simulated amplitudes tend to be less than the observed ones. The progress is welcome news because it will lead, over some time, to an improved representation of Nordic Seas processes in large-scale ocean-sea ice models and eventually coupled climate models.

Models have recently been used to put decadal variability and observed trends into a larger scale perspective, connecting individual observed time series with the large-scale atmospheric forcing fields and the oceanic conditions in adjacent basins. For instance, model experiments were important tools in identifying fluctuations in the fresh water flux out of the Arctic and their pathways through the Nordic Seas. Similarly, the fate of Atlantic water entering the Nordic Seas in the passages through GSR, the subsequent modification of the water masses in the Nordic Seas, and the branching into different paths entering the Arctic and recirculating within the Nordic Seas have been the subject of analysis of ocean-sea ice hindcast experiments. This led to the identification of multiple Arctic warming events with the 1990s warming as an outstanding event for at least the last 50 years. Long-term observations at key locations that have been taken in the Nordic Seas [e.g. Blindheim and Østerhus, this issue] have proven invaluable for model evaluation and also as indicators for dramatic developments in the marine climate system of the region.

Despite this recent progress, many difficulties remain to be overcome and important model improvements to be realized. As has been demonstrated here, different model system like NAOSIM and MICOM provide different results under similar atmospheric forcing. These differences pertain to important fluxes through the Nordic Seas and would be of climatic importance if they existed in the real ocean. The cause for the differences are basically unknown and clarification of the cause would require systematic intercomparison efforts as have taken place for the Atlantic (e.g. DYNAMO) and the Arctic (AOMIP) ocean basins. Clearly, some processes like the exchanges with the Arctic through Fram Strait, the interaction of the EGC with the interior of the Greenland Sea and the overflows to the subpolar North Atlantic require enhanced resolution and perhaps better or new parameterisation schemes of small scale processes. New models with significantly higher horizontal and vertical resolution have recently been implemented or are planned for the immediate future.

The wealth of existing historical data and the continuous stream of data from observational programs calls for a more systematic use of models. This paper has been limited to studies of the present day climate state. The presented discussion is, however, directly transferable and applicable to studies of past and future climate states, as well for studies of the marine biogeochemical cycles. It is therefore foreseen that available and forthcoming OGCMs, even OGCMs tailored for the small Nordic Seas region, will significantly contribute to improved understanding of 
Drange, Gerdes, Gao, Karcher, Kauker, and Bentsen (2005): Ocean General Circulation Modelling of the Nordic Seas, in The Nordic Seas: An Integrated Perspective (Drange, Dokken, Furevik, Gerdes and Berger, Eds.), AGU Monograph 158, American Geophysical Union, Washington DC, pp. 199-220.

the variability and stability properties of past, present and future climate states.

\section{APPENDIX}

\subsection{The Miami Isopycnic Co-ordinate Ocean Model (MICOM)}

The NERSC model used in this study is based on a mixture of version 2.7 and 2.8 of MICOM [Bleck et al., 1992], fully coupled to a sea-ice module consisting of the Hibler [1979] rheology in the implementation of Harder [1996], and the thermodynamics of Drange and Simonsen [1992].

The model system is identical to that used in Gao et al. [2005] to examine the transit time of the pole-ward flowing Atlantic Water in the Nordic Seas, and a modification of the model used by Furevik et al. [2002], Nilsen et al. [2003] and Bentsen et al. [2004] addressing the observed and simulated salinity in the Nordic Seas, the variability of the volume transports across GSR, and the inter-annual to decadal-scale variability of the Atlantic MOC, respectively. The main modifications to the Furevik et al. [2002], Nilsen et al. [2003] and Bentsen et al. [2004] studies are reduced strength of the parameterised isopycnal and diapycnal mixing rates, the latter based on the CFC model evaluation study by Gao et al. [2003]. The applied model grid configuration is identical to that in Furevik et al. [2002], Nilsen et al. [2003] and Gao et al. [2005], but has doubled horizontal resolution compared to that in Bentsen et al. [2004].

Specifically, the horizontal grid resolution is about 40 $\mathrm{km}$ in the Northern North Atlantic and the Nordic Seas region, and the diffusive velocities (diffusivities divided by the size of the grid cell) for layer interface diffusion, momentum dissipation, and tracer (temperature and salt) dispersion are $0.015 \mathrm{~m} \mathrm{~s}^{-1}, 0.01 \mathrm{~m} \mathrm{~s}^{-1}$ and $0.0025 \mathrm{~m} \mathrm{~s}^{-1}$, respectively. The diapycnal mixing coefficient $K_{d}\left(\mathrm{~m}^{2} \mathrm{~s}^{-}\right.$ ${ }^{1}$ ) is parameterized as $K_{d}=5 \cdot 10^{-8} / N$, where $N\left(\mathrm{~s}^{-1}\right)$ s the Brunt-Väisälä frequency. Consequently, the value of tracer dispersion and diapycnal mixing are factors 2 and 6, respectively, below those used in Furevik et al. [2002], Nilsen et al. [2003] and Bentsen et al. [2004].

The applied forcing is identical to all of the abovementioned studies, i.e., daily atmospheric re-analysis fields from 1948 to present provided by the NCAR/NCEP re-analyses project [Kalnay et al., 1996]. The results presented here are based on integration cycle number two and three with NCAR/NCEP forcing, where cycle two is initialised with the full ocean state at the end of cycle one (the spin-up cycle), and cycle three is initiated with the full ocean state at the end of cycle two.

A $20 \mathrm{~km}$ version of the model system is available, but output from this model version is not used in this review. See Hátún et al. [this issue] for an example of the $20 \mathrm{~km}$ version of MICOM.

\subsection{The North Atlantic/Arctic Ocean-Sea-Ice-Model (NAOSIM)}

AWI maintains a hierarchy of coupled sea ice-ocean models called NAOSIM (North Atlantic/Arctic OceanSea Ice Model). Models from the NAOSIM hierarchy are described in some detail in Karcher et al. [2003] and Köberle and Gerdes [2003]. Results for this paper were taken from an experiment with a quarter degree version of the model that is described in Gerdes et al. [this issue]. The model was forced with daily mean 2-meter air temperature, dew point temperature, cloudiness, precipitation, wind speed, and surface wind stress. For the first 50 years of spin-up, a climatological mean seasonal cycle based on the period 1979-1993 with added typical daily variability [OMIP-climatology, Röske, 2001] is used. After the spin-up, the forcing consists of daily mean atmospheric data from the NCEP re-analysis for the period 1948-2001 [Kalnay et al., 1996]. Fresh water influx from rivers is not explicitly included. To account for river run-off and diffuse runoff from the land, as well as to include the effect of flow into the Arctic through the Bering Strait, a restoring flux with an adjustment time scale of 180 days is added to the surface freshwater flux [Gerdes et al., this issue]. The restoring flux is calculated in reference to annual mean climatological surface salinity data, constructed similarly to the initial data. The effect of the restoring flux on the surface salinity for this and other Arctic Ocean models is documented in Steele et al. [2001].

Acknowledgement. The European Union DG-XII Climate and Environment Programme has supported the OGCM activities at NERSC and AWI through the projects CONVECTION (contract EVK-CT-200000058), DYNAMITE (contract 003903), PREDICATE (EVK2-CT-1999-00020) and TRACTOR (EVK2-200000080). The model development at NERSC has in addition received support from the G. C. Rieber Foundations, the RegClim and ProClim projects under the Research Council of Norway, and the Vestnordisk Oceanclima programme under the Nordic Council of Ministers. The ocean modelling at AWI has also been funded by the German ministry for research and technology under the DEKLIM program (contract 01 LD 0047) and by the Deutsche Forschungsgemeinschaft via the SFB 512. Additional funds were made available through the Arctic Ocean Model Intercomparison Project (AOMIP). Dr. J. E. Ø. Nilsen (NERSC) provided valuable help with some of the figures and tables, and Mads Hvid Ribergaard provided the drifter data in Fig. 1. Comments from Torben Schmidt and three 
anonymous reviewers are also highly acknowledged. This is publication No A 97 from the Bjerknes Centre for Climate Research.

\section{REFERENCES}

Aukrust, T., Oberhuber, J.M., 1995. Modeling of the Greenland, Iceland and Norwegian Seas with a coupled sea ice-mixed layer-isopycnal ocean model. J. Geophys. Res. 100, 4771-4789.

Beckmann, A., Döscher, R., 1997. A method for improved representation of dense water spreading over topography in geopotential-coordinate models. J. Phys. Oceanogr. 27, 581591.

Beismann, J.-O., Barnier, B., 2004. Variability of the meridional overturning circulation of the North Atlantic: sensitivity to overflows of dense water masses. Ocean Dyn. 54, 92-106, DOI 10.1007/s10236-003-0088-x.

Bennett, A.F., 1992. Inverse methods in physical oceanography. Cambridge University Press, Cambridge, 346 pp.

Bentsen, M., Drange, H., Furevik, T., Zhou, T., 2004. Simulated variability of the Atlantic meridional overturning circulation, Clim. Dynam., doi: 10.1007/s00382-004-0397-x.

Biastoch, A., Käse, R.H., Stammer, D.H., 2003. The Sensitivity of the Greenland-Scotland Ridge Overflow to Forcing Changes. J. Phys. Oceanogr. 33, 2307-2319, doi: 10.1175/1520-0485(2003)033.

Bleck, R., 2002. An oceanic general circulation model framed in hybrid isopycnic-cartesian coordinates. Ocean Modelling 4, 55-88.

Bleck, R., Rooth, C., Hu, D., Smith, L.T., 1992. Salinitydriven thermocline transients in a wind- and thermohalineforced isopycnic coordinate model of the North Atlantic. $J$. Phys. Oceanogr. 22, 1486-1505.

Blumberg, A.F., Mellor, G.L., 1989. A description of a three-dimensional coastal ocean circulation model, in ThreeDimensional Coastal Ocean Models, N. Heaps (Ed.), pp. 1-16, American Geophysical Union, Washington, DC, 1987.

Böning, C.W., Dieterich, C., Barnier, B., Jia, Y., 2001. Seasonal cycle of meridional heat transport in the subtropical North Atlantic: a model intercomparison in relation to observations near $25^{\circ} \mathrm{N}$. Prog. Oceanogr. 48, 231-253.

Bönisch, G., Blindheim, J., Bullister, J.L., Schlosser, P., Wallace, D.W.R., 1997. Long-term trends of temperature, salinity, density, and transient tracers in the central Greenland Sea. J. Geophys. Res. 102, 18553-18571.

Bryan, K., 1969: A numerical model for the study of clirculation of the world oceans. J. Comput. Phys. 4, 347-376.

Budeus, G., Schneider, W., Krause, G., 1998. Winter convective events and bottom water warming in the Greenland Sea. J. Geophys. Res. 103, 18513-18527.

Canuto, V. M., Howard, A., Hogan, P., Cheng, Y., Dubovikov, M.S., Montenegro, LO.M., 2004. Modeling ocean deep convection. Ocean Modelling 7, 75-95.

Collins, M., Botzet, M., Carril, A., Drange, H., Jouzeau, A., Latif, M., Otterå, O.H., Pohlmann, H., Sorteberg, A., Sutton, R., Terray, L., 2005. Interannual to decadal climate predictability: A multi-perfect-model-ensemble study. $J$. Climate, conditionally accepted

Cox, M.D., 1984: A primitive equation three-dimensional model of the ocean. Report, GFDL Ocean Group, NOAA, Princeton Univ., Princeton, NJ.

Curry R., Dickson, R.R., Yashayaev, I., 2003. A Change in the Freshwater Balance of the Atlantic Ocean over the Past four decades. Nature 426, 826-829.

Dickson, B., Yashayaev, I., Meincke, J., Turell, B., Dye, S., Holfort, J., 2002. Rapid freshening of the deep North Atlantic Ocean over the past four decades. Nature 416, 832-837.
Döscher, R., Redler, R., 1997. The relative importance of northern overflow and subpolar deep convection for the North Atlantic Thermohaline circulation. J. Phys. Oceanogr. 27, 1894-1902.

Drange H, Simonsen, K., 1996. Formulation of air-sea fluxes in the ESOP2 version of MICOM. Technical Report 125, Nansen Environmental and Remote Sensing Center, Edv. Griegsv. 3A, N-5037 Solheimsviken, Norway.

Dutay, J.-C., et al., 2002. Evaluation of ocean model ventilation with CFC-11: comparison of 13 global ocean models. Ocean Modelling 4, 89-120.

DYNAMO Group (Barnard, S., Barnier, B., Beckmann, A., Böning, C.W., Coulibaly, M., de Cuevas, D., Dengg, J., Dieterich, C., Ernst, U., Herrmann, P., Jia, Y., Killworth, P.D., Kröger, J., Lee, M.-M., LeProvost, C., Molines, J.-M., New, A. L., Oschlies, A., Reynaud, T., West, L.J., Willebrand, J.), 1997. DYNAMO - Dynamics of North Atlantic Models. Simulation and assimilation with high resolution models. Berichte aus dem Institut für Meereskunde an der ChristianAlbrechts-Universität Kiel, 294, 334 pp.

Engedahl H, Ådlandsvik, B., Martinsen, E.A., 1998. Production of monthly mean climatological archives for the Nordic Seas. J. Mar. Syst. 14, 1-26.

England, M., Maier-Reimer, E., 2001. Using chemical tracers to assess ocean models. Rev. Geophys. 39, 29-70.

Evensen, G., 2003: The Ensemble Kalman Filter: theoretical formulation and practical implementation. Ocean Dynamics 53, 343-367, DOI 10.1007/s10236-003-0036-9

Furevik, T., Bentsen, M., Drange, H., Johannessen, J., Korablev, A., 2002. Temporal and spatial variability of the sea surface salinity in the Nordic Seas. J. Geophys. Res. 107, doi:10.1029/2001JC001118.

Gao Y., Drange, H., Bentsen, M., Johannessen, O.M., 2005.

Tracer-derived transient time of the eastern waters in the Nordic Seas. Tellus, in press.

Gao, Y., Drange, H., Bentsen, M., 2003. Effects of diapycnal and isopycnal mixing on the ventilation of CFCs in the North Atlantic in an isopycnic coordinate OGCM. Tellus 55B, 837-384.

Gao, Y., Drange, H., Bentsen, M., Johannessen, O.M., 2004. Simulating the transport of radionuclides in the North AtlanticArctic region. J. Environ. Radioactivity 71, 1-16, doi:10.1016/S0265-931X(03)00108-5.

Gaspar, P., 1988. Modeling the seasonal cycle of the upper ocean. J. Phys. Oceanogr. 18, 161-180.

Gerdes, R., 1993. A primitive equation ocean circulation model using a general vertical coordinate transformation, Part 2 application to an overflow problem. J. Geophys. Res. 98, 14703-14726.

Gerdes, R., M. Karcher, F. Kauker, and U. Schauer, 2003. Causes and development of repeated Arctic Ocean warming events. Geophys. Res. Lett. 30, doi: 10.1029/2003GL018080.

Ginis, I., Richardson, R.A., Rothstein, L.M., 1998. Design of a multiply nested primitive equation ocean model. Mon. Wea. Rev. 126, 1054-1079.

Goosse H., Gerdes, R., Kauker, F., Koeberle, C., 2004. Influence of the exchanges between the Atlantic and the Arctic on sea-ice volume variations during the period 1948-1997. J. Climate 17, 1294-1305.

Griffies, S.M., Böning, C., Bryan, F.O., Chassignet, E.P., Gerdes, R., Hasumi, H., Hirst, A., Treguier, A.-M., Webb, D., 2000. Developments in ocean climate modelling. Ocean Modelling 2, 123-192.

Griffies, S.M., Harrison, M.J., Pacanowski, R.C., Rosati, A., 2004. A technical guide to MOM4, NOAA/Geophysical Fluid Dynamics Laboratory, Princeton, USA, 337pp.

Haak, H., Jungclaus, J., Mikolajewicz, U., Latif, M., 2003. Formation and propagation of great salinity anomalies. Geophys. Res. Lett. 30, DOI 10.1029/2003GL017065.

Häkkinen, S., 1991. Models and their applications in polar oceanography, in Polar Oceanography (Ed. W.O. Smith), Pergamon Press. 
Drange, Gerdes, Gao, Karcher, Kauker, and Bentsen (2005): Ocean General Circulation Modelling of the Nordic Seas, in The Nordic Seas: An Integrated Perspective (Drange, Dokken, Furevik, Gerdes and Berger, Eds.), AGU Monograph 158, American Geophysical Union, Washington DC, pp. 199-220. Official version available from $\underline{\mathbf{A G U}}$.

Häkkinen, S., 1995. Simulated interannual variability of the Greenland Sea deep water formation and its connection to surface forcing. J. Geophys. Res. 100, 4761-4770.

Häkkinen, S., 1999. Variability of the simulated meridional heat transport in the North Atlantic for the period 1951-1993.

J. Geophys. Res. 104, 10991-11007.

Häkkinen, S., Mellor, G.L., 1992. Modeling the seasonal variability of a coupled Arctic ice-ocean system. J. Geophys. Res. 97, 20,285-20,304.

Häkkinen, S., 2002. Surface salinity variability in the northern North Atlantic during recent decades. J. Geophys. Res. 107, 10.1029/2001JC000812.

Hallberg, R., 2000. Time integration of diapycnal diffusion and Richardson number-dependent mixing in isopycnal soordinate ocean models. Mon. Wea. Rev. 128, 1402-1419.

Hansen, B., Østerhus, S., 2000. North Atlantic - Norwegian Sea Exchanges. Prog. Oceanogr. 45,109-208.

Hansen, B., Østerhus, S., Quadfasel, D., Turrell, W., 2004. Already the day after tomorrow? Science 305, 953-954, DOI: 10.1126/science.1100085.

Harder, M., 1996: Dynamik, Rauhigkeit und Alter des Meereises in der Arktis. PhD thesis Alfred-Wegener-Institut für Polar- und Meeresforschung, Bremerhaven, Germany. 124 pp.

Heburn, G.W., Johnson, C.D., 1995. Simulations of the mesoscale circulation of the Greenbland-Iceland-Norwegian Seas. J. Geophys. Res. 100, 4921-4941.

Heggelund Y., Berntsen, J., 2002. A method for analysing nesting techniques for the linearized shallow water equations. Int. J. Numer. Meth. Fl. 38, 163-185.

Hibler, III W.D., 1979. A Dynamic Thermodynamic Sea Ice Model. J. Phys. Oceanogr. 9, 815-846.

Holland, D.M., Mysak, L.A., Oberhuber, J.M., 1996. Numerical simulation of the mixed-layer circulation in the Arctic Ocean. J. Geophys. Res. 101, 1111 - 1128.

Hopkins, T.S., 1991. The GIN Sea - a synthesis of its physical oceanography and literature review 1972-1985. Earth-Sci. Rev. 30, 175-318.

Ingvaldsen, R.B, Asplin, L., Loeng, H., 2004. The seasonal cycle in the Atlantic transport to the Barents Sea during 19972001. Cont. Shelf Res. 24, 1015-1032.

Jacobsen, P.K., Ribergaard, M.H., Quadfasel, D., Schmith, T., Hughes, C.W., 2003. Near surface circulation in the northern North Atlantic as inferred from Lagrangian drifters: variability from the mesoscale to interannual. J. Geophys. Res. 108, 3251.

Jensen, T.G., 1998. Open boundary conditions in stratified ocean models. J. Mar. Sys. 16, 297-322.

Johannessen O.M., Shalina, E.V., Miles, M., 1999. Satellite evidence for an Arctic Sea Ice cover in transformation. Science 286, 1937-1939.

Kalnay, E., et al., 1996. The NCEP/NCAR 40-year reanalysis project. Bullet. Amer. Meteorol. Soc. 77, 437-471.

Kampf, J., Backhaus, J.O., 1999. Ice-ocean interactions during shallow convection under conditions of steady winds: three dimensional numerical studies. Deep-Sea Res. 46(6/7), 1335-1355.

Karcher, M.J., Gerdes, R., Kauker, F., Köberle, C., 2003. Arctic warming: Evolution and spreading of the 1990s warm event in the Nordic Seas and the Arctic Ocean. J. Geophys. Res. 108, 3034, doi:10.1029/2001JC001265.

Karcher, M.J., Gerland, S., Harms, I.H., Iosjpe, M., Heldal, GH.E., Kershaw, P.J., Sickel, M., 2004. The dispersion of ${ }^{99}$ Tc in the Nordic Seas and the Arctic Ocean: A comparison of model results and observations. J. Environm. Radioactivity 74, 185-198.

Karcher, M.J., Oberhuber, J.M., 2002. Pathways and modification of the upper and intermediate waters of the Arctic Ocean. J. Geophys. Res. 107, 10, 1029/2000JC000530.

Kauker, F., Gerdes, R., Karcher, M., Köberle, C., Lieser, J.L., 2003. Variability of Arctic and North Atlantic sea ice: A combined analysis of model results and observations from
1978 to 2001. J. Geophys. Res. 108, 3182. doi: 10.1029/2002JC001573.

Killworth, P.D., Edwards, N.R., 1999. A turbulent bottom boundary layer code for use in numerical ocean models. $J$. Phys. Oceanogr. 29, 1221-1238.

Killworth, P.D., 2003. Inclusion of the bottom boundary layer in ocean models, In: Muller, P. (Ed.) Near-Boundary Processes and Their Parameterization, Proceedings of the 13th 'Aha Huliko'a Hawaiian Winter Workshop, 21-24 Jan 2003, Honolulu HI, University of Hawaii SOEST, 2003, 177185.

Köberle, C., Gerdes, R., 2003. Mechanisms determining the variability of Arctic sea ice conditions and export. J. Climate 16, 2843-2858.

Kösters, F., Käse, R.H., Schmittner, A., Herrmann, P., 2005. The effect of Denmark Strait Overflow on the Atlantic meridional overturning circulation. Geophys. Res. Lett., in press.

Legutke, S., 1991. A numerical investigation of the circulation in the Greenland and Norwegian Seas. J. Phys. Oceanogr. 21, 118-148.

Marshall, J., Schott, F., 1999. Open-ocean convection: observations, theory, and models. Rev. Geophys. 37, 1-64.

Martinsen, E.A., Engedahl, H., 1987. Implementation and testing of a lateral boundary scheme as an open boundary condition in a barotropic ocean model. Coastal Eng. 11, 603627.

Mauritzen, C., Häkkinen, S., 1999. On the relationship between dense water formation and the "Meridional Overturning Cell” in the North Atlantic Ocean. Deep-Sea Res. 46, 877-894.

Mellor, G.L., Häkkinen, S., 1994. A review of coupled iceocean models. In: The Polar Oceans and their Role in Shaping the Global Environment. Geophysical Monograph, 85, 525pp.

Mertz, G., Wright, D.G., 1992. Interpretations of the jebar term. J. Phys. Oceanogr. 22, 301-305.

Müller, P., Willebrand, J., 1989. Equations for oceanic motions. In Landolt-Börnstein, Group V, Oceanography, Volume $3 b$, pages 1.14. J. Sündermann (Ed.), Springer Verlag, Berlin

New, A.L., Barnard, S., Herrmann, P., Molines, J.M., 2001. On the origin and pathway of the saline inflow to the Nordic Seas: insigths from models. Prog. Oceanogr 48, 123-161.

Nies, H., Harms, I.H., Karcher, M.J., Dethleff, D., Bahe, C., Kuhlman, G., Kleine, E., Loewe, P., Oberhuber, J.M.,

Backhaus, J.O., Matishov, D., Stepanov, A., Vasiliev, O.F., 1998. Anthropogenic radioactivity in the Nordic Seas and the Arctic Ocean: Results from a joint German project. Deutsche Hydrographische Zeitung, (German Journal of Hydrography) 50, 313-343.

Nilsen, J.E.Ø., Gao, Y., Drange, H., Furevik, T., Bentsen, M., 2003. Simulated North Atlantic-Nordic Seas water mass exchanges in an isopycnic coordinate OGCM. Geophys. Res. Lett. 30, doi: 10.1029/2002GL016597.

Oberhuber, J.M., 1993. Simulation of the Atlantic circulation with a coupled sea-ice mixed layer-isopycnal general circulation model, Part I: Model description. J. Phys. Oceanogr. 23, 808-829.

Olsson, K.A., Jeansson, E., Anderson, L.G., Hansen, B. Eldevik, T., Kristiansen, R., Messias, M.-J., Johannessen, T., Watson, A.J., 2005. Intermediate water from the Greenland Sea in the Faroe Bank Channel: spreading of released sulphur hexafluoride. Deep Sea Res. I 52, 279-294.

Østerhus, S., Turrell, W.R., Jónsson, S., Hansen, B., 2005. Measured volume, heat, and salt fluxes from the Atlantic to the Arctic Mediterranean. Geophys. Res. Lett. 32, L07603, doi:10.1029/2004GL022188.

Palma, E.D., Matano, R.P., 2000. On the implementation of open boundary conditions for a general circulation model: the three-dimensional case. J. Geophys. Res. 105, 8605-8627.

Paluskiewicz, T., Romea, R.D., 1997. A one-dimensional model for the parameterization of deep convection in the ocean. Dyn. Atm. Ocean 26, 95-130. 
Drange, Gerdes, Gao, Karcher, Kauker, and Bentsen (2005): Ocean General Circulation Modelling of the Nordic Seas, in The Nordic Seas: An Integrated Perspective (Drange, Dokken, Furevik, Gerdes and Berger, Eds.), AGU Monograph 158, American Geophysical Union, Washington DC, pp. 199-220. Official version available from $\underline{\mathbf{A G U}}$.

Perkins, A.L., Smedstad, L.F., Blake, D.W., Heburn, G.W., 1997. A new nested boundary condition for a primitive equation ocean model. J. Geophys. Res. 102, 3483-3500.

Proshutinsky, A., M. Steele, J. Zhang, G. Holloway, N. Steiner, Häkkinen, S., Holland, D., Gerdes, R., Koeberle, C., Karcher, M., Johnson, M., Maslowski, W., Walczowski, W., Hibler, W., Wang, J., 2001.Multinational Effort Studies Differences Among Arctic Ocean Models. EOS Transactions, American Geophysical Union, 82, 637, 643, 644.

Roberts, M.J., Wood, R.A., 1997. Topographic Sensitivity Studies with a Bryan-Cox-Type Ocean Model. J. Phys. Oceanogr. 27, 823-836.

Röske, F., 2001. An atlas of surface fluxes based on the ECMWF Re-analysis: A climatological dataset to force global ocean general circulation models. Max-Planck-Institut fur Meteorologie Report 323, $31 \mathrm{pp}$.

Sarkisyan, A. S., Ivanov, V.F., 1971. Joint effect of baroclinicity and borrom relief as an important factor in the dynamics of sea currents. Izv. Acad. Sci. USSR, Atmos. Oceanic Phys. 7, 173-178.

Schauer, U., Fahrbach, E., Østerhus, S., Rohardt, G., 2004. Arctic warming through the Fram Strait - Oceanic heat transport from three years of measurements. J. Geophys. Res. 109, C06026, DOI: 10.1029/2003JC001823.

Schlosser, P., Bönisch, G., Rhein, M., Bayer, R., 1991. Reduction of deepwater formation in the Greenland Sea during the 1980s: Evidence from tracer data. Science 251, 1054-1056.

Semtner, A. J. Jr., 1976a. Numerical simulation of the Arctic Ocean circulation. J. Phys. Oceanogr. 6, 409-425.

Semtner, A. J. Jr., 1976b. A numerical model for the thermodynamic growth of sea ice in numerical investigations of climate. J. Phys. Oceanogr. 6, 379-389.

Semtner, A. J. Jr., 1995. Modeling ocean circulation. Science 269, 1379-1385.

Shi, X.B., Rød, L.P., Hackett, B., 2001. Variability of the Denmark Strait overflow: A numerical study. J. Geophys. Res. 106, 22277-22294.

Simonsen, K., Haugan, P.M., 1996. Heat budgets of the Arctic Mediterranean and sea surface heat flux parametrizations for the Nordic Seas. J. Geophys. Res. 101, 6553-6576.

Stammer, D., Wunsch, C., Giering, R., Eckert, C., Haimbach, P., Marotzke, J., Adcroft, A., Hill, C.N., Marshall, J., 2003a. Volume, heat and freshwater of the global ocean circulation 1993-2000, estimated from a general circul;ation model constrained by World Ocean Circulation Experiment (WOCE) data. J. Geophys. Res. 108, 3007, doi:10.1029/2001JC001115.

Stammer, D., Wunsch, C., Giering, R., Eckert, C., Haimbach, P., Marotzke, J., Adcroft, A., Hill, C.N., Marshall, J., 2003b: Global ocean circulation during 1992-1997, estimated from ocean observations and a general circulation model. J. Geophys. Res. 108, 3118,

doi:10.1029/2001JC000888.

Steele, M., Ermold, W., Holloway, G., Häkkinen, S., Holland, D.M., Karcher, M., Kauker, F., Maslowski, W., Steiner, N., Zhang, J., 2001. Adrift in the Beaufort Gyre: A model intercomparison. Geophys. Res. Lett 28, 2935-2838.

Steiner, N., Holloway, G., Gerdes, R., Häkkinen, S., Holland, D.M., Karcher, M., Kauker, F., Maslowski, W., Proshutinsky, A., Steele, M., Zhang, J., 2004. Comparing modeled streamfunction, heat and freshwater content in the Arctic Ocean. Ocean Modelling 6, 265-284, doi: doi:10.1016/S1463-5003(03)00013-1.

Stevens, D.P., 1991. A numerical ocean circulation model of the Norwegian and Greenland Seas. Prog. Oceanog. 27, 365402.

Toggweiler, J., Dixon, K., Bryan, K., 1989. Simulations of radiocarbon in a coarse-resolution world ocean model, 1 , Steady state prebomb distributions. J. Geophys. Res. 94, 82178242.

Uotila, P., Holland, D.M., Morales Maqueda, M.A., Häkkinen, S., Holloway, G., Karcher, M., Kauker, F., Steele,
M., Yakovlev, N., Zhang, J., Proshutinsky, A., 2005: An energy-diagnostics intercomparison of coupled ice-ocean Arctic models. Ocean Modelling,

doi:10.1016/j.ocemod.2004.11.003, in press.

Watson, A.J., Messias, M.-J., Fogelquist, E., Scoy, K.V., Johannessen, T., Rey, F., Tanhua, T., Carse, F., Simonsen, K., Ledwell, J., Jansen, E., Cooper, D., Kruepke, J., Guilyardi, E., 1999. Mixing in the Greeland Sea gyre studied by tracer release. Nature 401, 901-904.

Willebrand, J., Barnier, B., Boning, C., Dieterich, C., Killworth, P.D., le Provst, C., Jia, Y., Molines, J.-M., New, A.L., 2001. Ciculation characteristics in three eddy-permitting models of the North Atlantic. Prog. Oceanogr. 48, 123-161.

H. Drange, Nansen Environmental and Remote Sensing Center and Bjerknes Centre for Climate Research, Thormhølensgt. 47, 5006 BERGEN, Norway (email:

helge.drange@nersc.no)

R. Gerdes, Alfred Wegner Institute for Polar and Marine Research, Bussestrasse 24, 27570 BREMERHAVEN, Germany (email: rgerdes@awi-bremerhaven.de)

Y. Gao, Nansen Environmental and Remote Sensing Center and Bjerknes Centre for Climate Research, Thormhølensgt. 47, 5006 BERGEN, Norway (email: yongqi.gao@nersc.no)

M. Karcher, Alfred Wegner Institute for Polar and Marine Research, Bussestrasse 24, 27570 BREMERHAVEN, Germany (email: mkarcher@awi-bremerhaven.de)

F. Kauker, Alfred Wegner Institute for Polar and Marine Research, Bussestrasse 24, 27570 BREMERHAVEN, Germany (email: fkauker@awi-bremerhaven.de)

M. Bentsen, Nansen Environmental and Remote Sensing Center and Bjerknes Centre for Climate Research, Thormhølensgt. 47, 5006 BERGEN, Norway (email: mats.bentsen@nersc.no) 
Table 1. Simulated northward, southward, and net northward (northward-southward) volume (Sv), heat flow (TW) and fresh water flux (0.01 Sv) through the Denmark Strait (DS), across the Iceland-Faroe Ridge (IFR), between the Faroes and Shetland (FS), across the Barents Opening (BO) and through the Fram Strait (FS) in MICOM and NAOSIM. The heat flows and fresh water fluxes are computed and accumulated online (i.e., time step by time step). The heat flows are given relative to $T=0{ }^{\circ} \mathrm{C}$ and the fresh water fluxes relative to $S=34.8$. Negative heat and fresh water fluxes means that the heat and fresh water transports (relative to $T=0{ }^{\circ} \mathrm{C}$ and $S=34.8$ ) are directed opposite to the flow. Due to round-off errors, the volume transport budgets balance within 0.1 to $0.2 \mathrm{~Sv} . \sigma_{V}$ is standard deviation.

\begin{tabular}{|c|c|c|c|c|c|c|c|c|c|c|}
\hline Section & $\mathbf{D}$ & & I & & & $\mathbf{S}$ & & $\mathbf{O}$ & $\mathbf{F}$ & \\
\hline \multicolumn{11}{|c|}{ Northward volume transports (Sv) } \\
\hline & $\overline{F_{V}}$ & $\sigma_{V}$ & $\overline{F_{V}}$ & $\sigma_{V}$ & $\overline{F_{V}}$ & $\sigma_{V}$ & $\overline{F_{V}}$ & $\sigma_{V}$ & $\boldsymbol{F}_{V}$ & $\sigma_{V}$ \\
\hline NAOSIM & 2.0 & .13 & 3.5 & .33 & 3.8 & .45 & 2.7 & .34 & 3.2 & .49 \\
\hline MICOM & 1.1 & .16 & 4.5 & .42 & 3.6 & .46 & 4.1 & .33 & 3.8 & .63 \\
\hline \multicolumn{11}{|c|}{ Southward volume transports (Sv) } \\
\hline & $\boldsymbol{F}_{V}$ & $\sigma_{V}$ & $F_{V}$ & $\sigma_{V}$ & $F_{V}$ & $\sigma_{V}$ & $F_{V}$ & $\sigma_{V}$ & $F_{V}$ & \\
\hline NAOSIM & 7.4 & .49 & 1.2 & .21 & 0.9 & .07 & 0.7 & .13 & 5.1 & \\
\hline MICOM & 3.7 & .48 & 2.4 & .32 & 2.5 & .26 & 2.0 & .37 & 5.3 & .62 \\
\hline
\end{tabular}

Net (northward - southward) volume transports (Sv)

\begin{tabular}{|c|c|c|c|c|c|c|c|c|c|c|}
\hline & $\boldsymbol{F}_{V}$ & $\sigma_{V}$ & $\boldsymbol{F}_{V}$ & $\sigma_{V}$ & $\boldsymbol{F}_{V}$ & $\sigma_{V}$ & $\boldsymbol{F}_{V}$ & $\sigma_{V}$ & $\boldsymbol{F}_{V}$ & $\sigma_{V}$ \\
\hline NA & -5.4 & .46 & 2.3 & .36 & 2.9 & .48 & 2.0 & .40 & -1.9 & .33 \\
\hline & -2.7 & .49 & 2.0 & .37 & 1.2 & .69 & 2.1 & .32 & -1.5 & .36 \\
\hline \multicolumn{11}{|c|}{ Northward heat transports (TW) } \\
\hline & $F_{H}$ & $\sigma_{H}$ & $F_{H}$ & $\sigma_{H}$ & $F_{H}$ & $\sigma_{H}$ & $F_{H}$ & $\sigma_{H}$ & $F_{H}$ & $\sigma_{H}$ \\
\hline & 26 & 3.5 & 101 & 10.8 & 137 & 16.1 & 49 & 8.7 & 28 & 6.7 \\
\hline & 26 & 3.4 & 106 & 16.1 & 136 & 15.6 & 86 & 8.6 & 25 & 2.8 \\
\hline \multicolumn{11}{|c|}{ Southward heat transports (TW) } \\
\hline & $F_{H}$ & $\sigma_{H}$ & $F_{H}$ & $\sigma_{H}$ & $F_{H}$ & $\sigma_{H}$ & $F_{H}$ & $\sigma_{H}$ & $\boldsymbol{F}_{\boldsymbol{H}}$ & $\sigma_{H}$ \\
\hline & 22 & 7.2 & 29 & 5.3 & 14 & 1.5 & 5 & 1.5 & -5 & 2.7 \\
\hline MICOM & 7 & 1.2 & 37 & 6.5 & 24 & 5.5 & 21 & 4.3 & 24 & 5.2 \\
\hline
\end{tabular}

\begin{tabular}{lcccccccccc}
\multicolumn{10}{c}{ Net (northward - southward) heat transports (TW) } \\
\hline & $\boldsymbol{F}_{\boldsymbol{H}}$ & $\sigma_{H}$ & $\boldsymbol{F}_{\boldsymbol{H}}$ & $\sigma_{H}$ & $\boldsymbol{F}_{\boldsymbol{H}}$ & $\sigma_{H}$ & $\boldsymbol{F}_{\boldsymbol{H}}$ & $\sigma_{H}$ & $\boldsymbol{F}_{\boldsymbol{H}}$ & $\sigma_{H}$ \\
NAOSIM & $\mathbf{4}$ & 6.1 & $\mathbf{7 2}$ & 11.6 & $\mathbf{1 2 3}$ & 16.5 & $\mathbf{4 4}$ & 8.5 & $\mathbf{3 3}$ & 6.6 \\
MICOM & $\mathbf{1 9}$ & 3.8 & $\mathbf{6 9}$ & 12.1 & $\mathbf{1 1 2}$ & 19.4 & $\mathbf{6 5}$ & 6.8 & $\mathbf{1}$ & 4.2
\end{tabular}

\begin{tabular}{lcccccccccc}
\multicolumn{11}{c}{ Northward salt transports (0.01 Sv) } \\
\hline & $\boldsymbol{F}_{S}$ & $\sigma_{S}$ & $\boldsymbol{F}_{S}$ & $\sigma_{S}$ & $\boldsymbol{F}_{S}$ & $\sigma_{S}$ & $\boldsymbol{F}_{S}$ & $\sigma_{S}$ & $\boldsymbol{F}_{S}$ & $\sigma_{S}$ \\
NAOSIM & $\mathbf{- 0 . 6}$ & 0.3 & $\mathbf{3 . 6}$ & 0.4 & $\mathbf{5 . 1}$ & 0.6 & $\mathbf{1 . 2}$ & 0.3 & $\mathbf{- 0 . 2}$ & 0.4 \\
MICOM & $\mathbf{- 0 . 4}$ & 0.3 & $\mathbf{3 . 4}$ & 0.8 & $\mathbf{4 . 8}$ & 0.7 & $\mathbf{0 . 2}$ & 0.5 & $\mathbf{2 . 0}$ & 1.6
\end{tabular}

\begin{tabular}{lcccccccccc}
\multicolumn{10}{c}{ Southward salt transports (0.01 Sv) } \\
\hline & $\boldsymbol{F}_{S}$ & $\sigma_{S}$ & $\boldsymbol{F}_{S}$ & $\sigma_{S}$ & $\boldsymbol{F}_{\boldsymbol{S}}$ & $\sigma_{S}$ & $\boldsymbol{F}_{\boldsymbol{S}}$ & $\sigma_{S}$ & $\boldsymbol{F}_{S}$ & $\sigma_{S}$ \\
NAOSIM & $\mathbf{- 9 . 2}$ & 1.8 & $\mathbf{1 . 1}$ & 0.2 & $\mathbf{0 . 8}$ & 0.1 & $\mathbf{- 0 . 1}$ & 0.2 & $\mathbf{- 6 . 7}$ & 1.6 \\
MICOM & $\mathbf{- 4 . 4}$ & 1.0 & $\mathbf{0 . 9}$ & 0.5 & $\mathbf{1 . 6}$ & 0.3 & $\mathbf{- 0 . 2}$ & 0.3 & $\mathbf{- 8 . 1}$ & 2.6
\end{tabular}

Net (northward - southward) salt transports (0.01 Sv)

\begin{tabular}{lcccccccccc}
\hline & $\boldsymbol{F}_{\boldsymbol{S}}$ & $\sigma_{S}$ & $\boldsymbol{F}_{\boldsymbol{S}}$ & $\sigma_{S}$ & $\boldsymbol{F}_{\boldsymbol{S}}$ & $\sigma_{S}$ & $\boldsymbol{F}_{\boldsymbol{S}}$ & $\sigma_{S}$ & $\boldsymbol{F}_{\boldsymbol{S}}$ & $\sigma_{S}$ \\
NAOSIM & $\mathbf{8 . 6}$ & 1.6 & $\mathbf{2 . 5}$ & 0.4 & $\mathbf{4 . 4}$ & 0.6 & $\mathbf{1 . 3}$ & 0.2 & $\mathbf{6 . 5}$ & 1.5 \\
MICOM & $\mathbf{4 . 0}$ & 0.8 & $\mathbf{2 . 5}$ & 0.5 & $\mathbf{3 . 2}$ & 0.8 & $\mathbf{0 . 4}$ & 0.4 & $\mathbf{1 0 . 2}$ & 3.0 \\
\hline
\end{tabular}


Table 2. Observed [Østerhus et al., 2005] and simulated properties of the Atlantic inflow to the Nordic Seas. Heat flow is relative to $0{ }^{\circ} \mathrm{C}$.

\begin{tabular}{lcccc}
\hline Atlantic inflow & Period & & \multicolumn{2}{c}{ Average fluxes } \\
\cline { 3 - 5 } & & & Volume & Heat \\
& & & Sv & TW \\
\hline Denmark Strait & $1994-2000$ & Observed & $\mathbf{0 . 7 5}$ & $\mathbf{1 9}$ \\
& & NAOSIM & 1.9 & 26 \\
& & MICOM & 0.8 & 24 \\
\hline Iceland-Faroe & Jun 1997 - Jun 2001 & Observed & $\mathbf{3 . 5}$ & $\mathbf{1 2 4}$ \\
& & NAOSIM & 3.4 & 98 \\
& & MICOM & 4.3 & 95 \\
\hline Faroe-Scotland & $1994-2000$ & Observed & $\mathbf{3 . 2}$ & $\mathbf{1 4 9}$ \\
& & NAOSIM & 4.0 & 147 \\
& & MICOM & 3.7 & 137
\end{tabular}




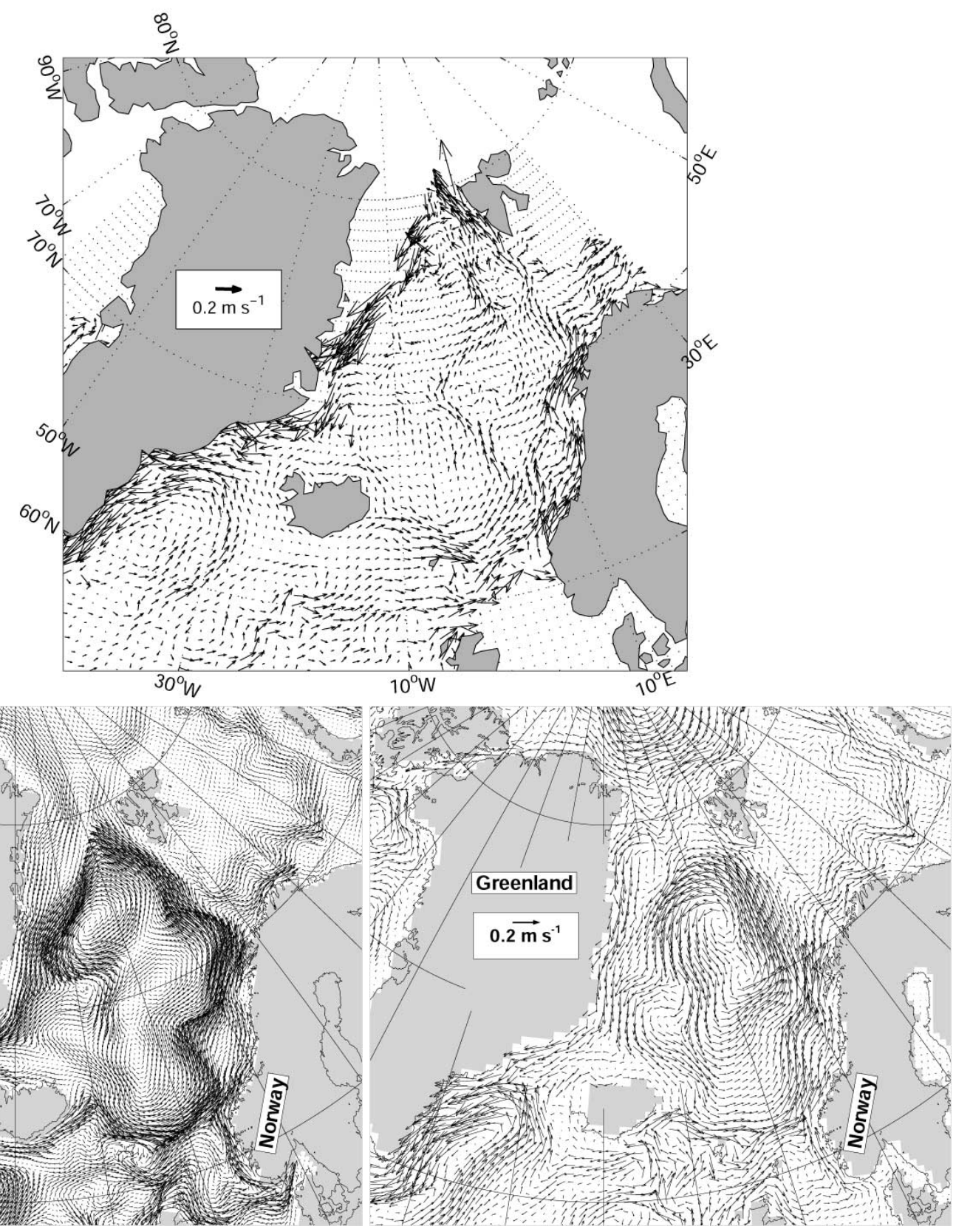

Figure 1. Upper panel: Observation-based near-surface circulation derived from drifters during the 1990s [Jacobsen et al., 2003]. Lower panels: Simulated velocity at $150 \mathrm{~m}$ averaged over the time period 1948-2002 by NAOSIM (left panel) and MICOM. 
Drange, Gerdes, Gao, Karcher, Kauker, and Bentsen (2005): Ocean General Circulation Modelling of the Nordic Seas, in The Nordic Seas: An Integrated Perspective (Drange, Dokken, Furevik, Gerdes and Berger, Eds.), AGU Monograph 158, American Geophysical Union, Washington DC, pp. 199-220. Official version available from $\underline{\mathbf{A G U}}$.

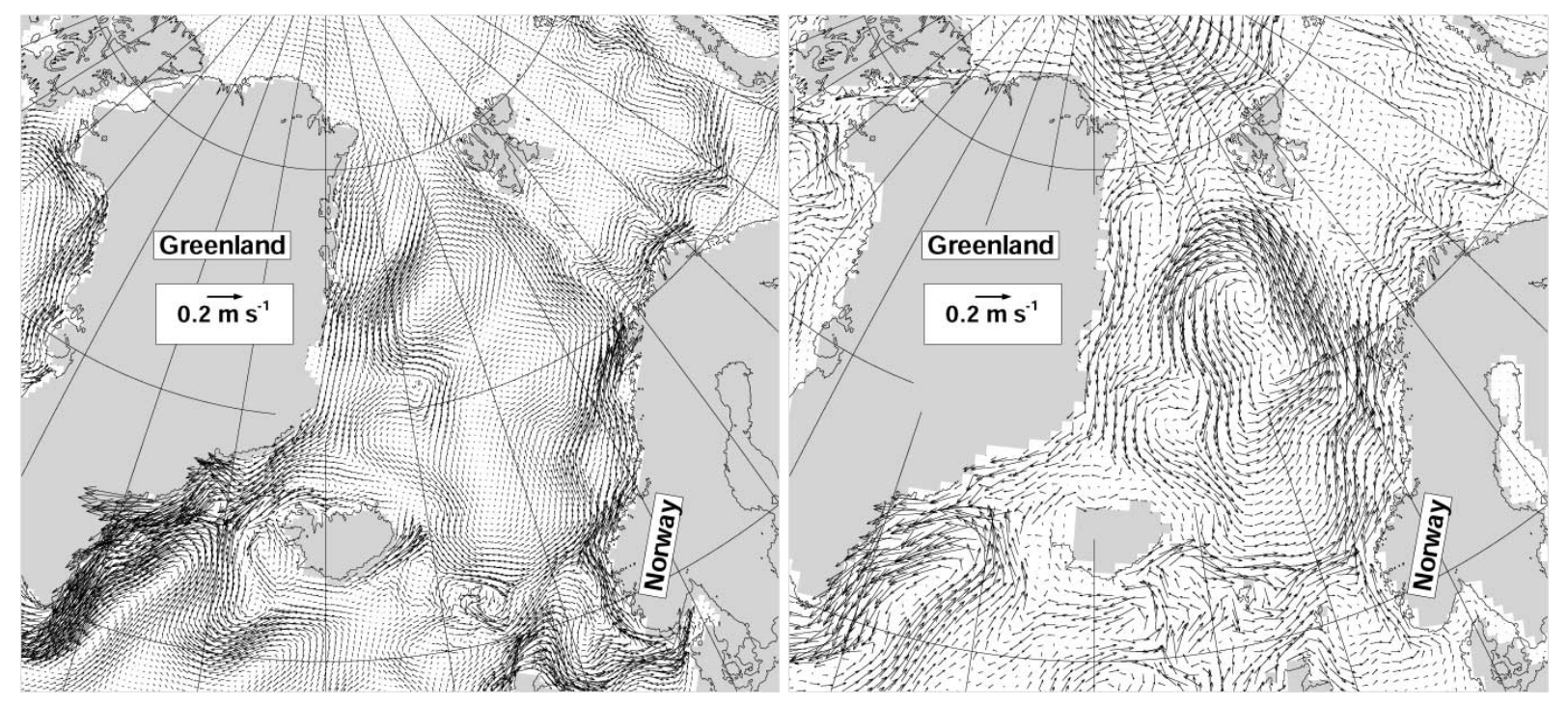

Figure 2. Simulated barotropic velocity field averaged over the time period 1948-2002 by NAOSIM (left panel) and MICOM. 


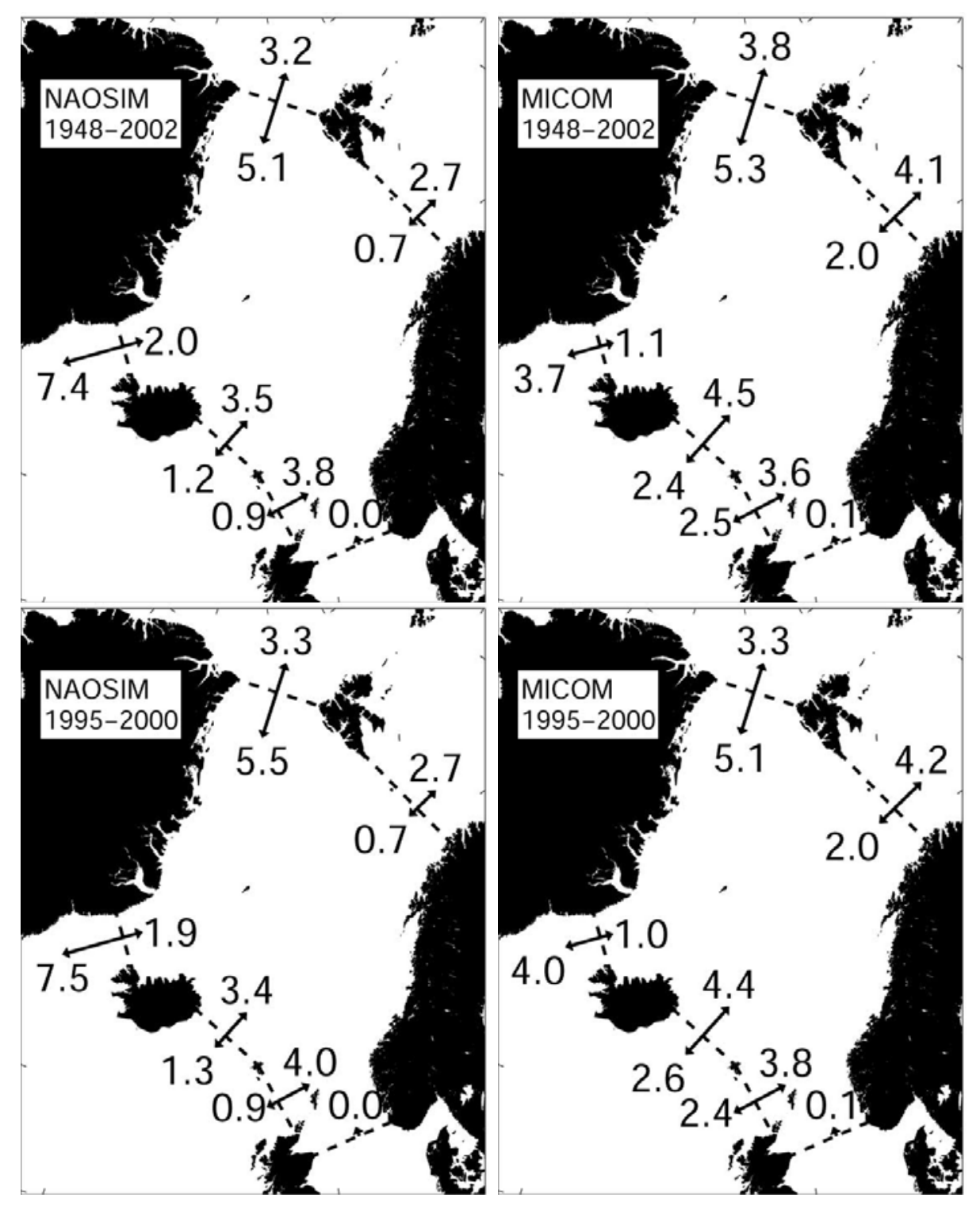

Figure 3. Simulated mean northward and southward volume fluxes (Sv) for the period 1948-2002 (upper panels) and for 1995-1999 (lower panels). NAOSIM to left and MICOM to right. Throughout the manuscript, the transports from MICOM are calculated online, i.e. time step by time step, whereas weekly output of velocity, temperature and salinity are used to diagnose the transports from NAOSIM. 


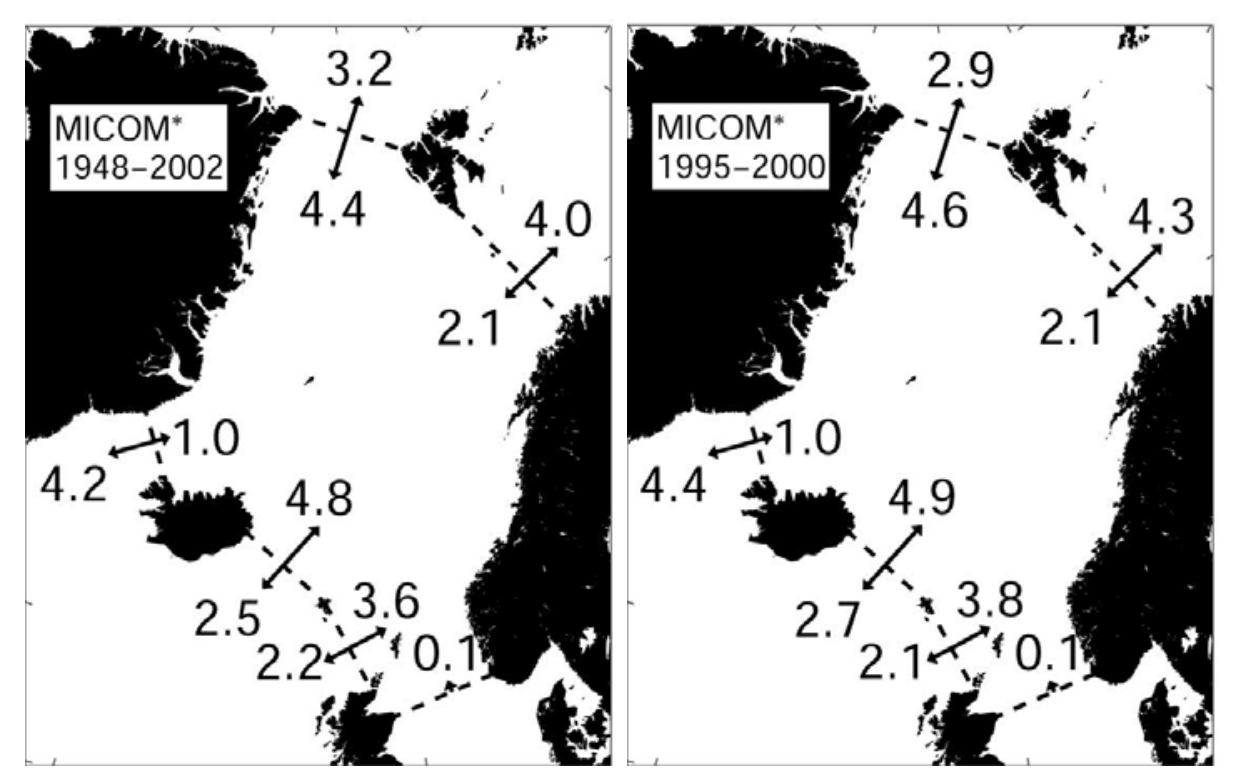

Figure 4. As Fig. 3, but for a realisation with MICOM, labelled MICOM*, starting in 1948 from the ocean state at the end of 2002 of the version of the model shown in Figs. 1-3. 

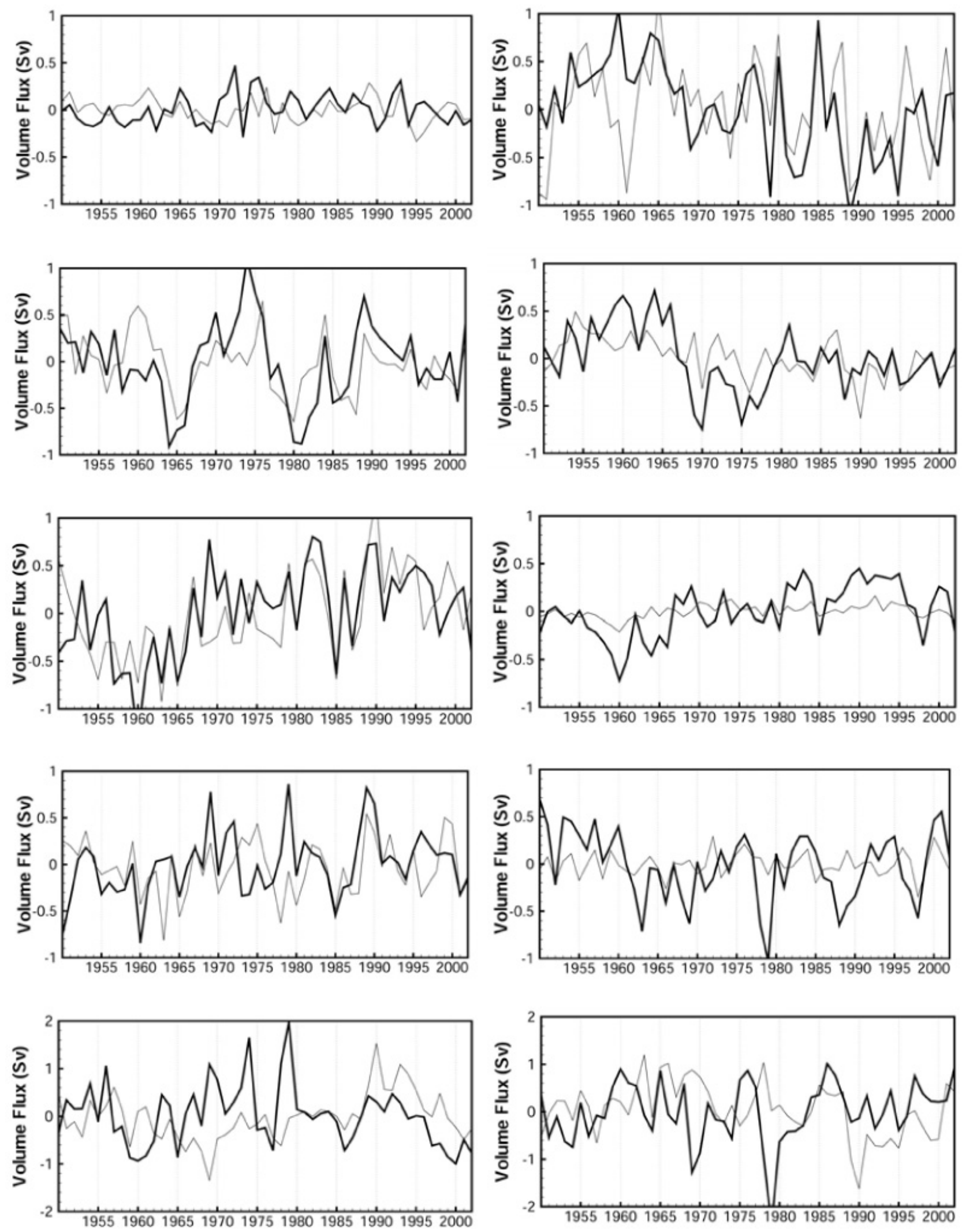

Figure 5. Simulated annual mean volume transport anomalies (Sv) for NAOSIM (thin lines) and MICOM. Left (right) column shows anomalies in net northward (southward) transports. The panels represent, from top, the Denmark Strait $(r=0.05 / \mathbf{0 . 4 6})$, the IcelandFaroe Ridge ( $r=\mathbf{0 . 5 1} / \mathbf{0 . 4 5})$, the Faroe-Scotland section $(r=\mathbf{0 . 5 9} / \mathbf{0 . 6 3})$, the Barents Opening $(r=\mathbf{0 . 2 8} / \mathbf{0 . 3 5})$, and the Fram Strait $(r=$ $-0.05 / 0.04$ ). The numbers in the parentheses give the (linear) correlation coefficient between the two model time series for the northward and southward volume fluxes, respectively, with the bold numbers identifying $95 \%$ or higher significance. The sections are indicated in Fig. 3. 


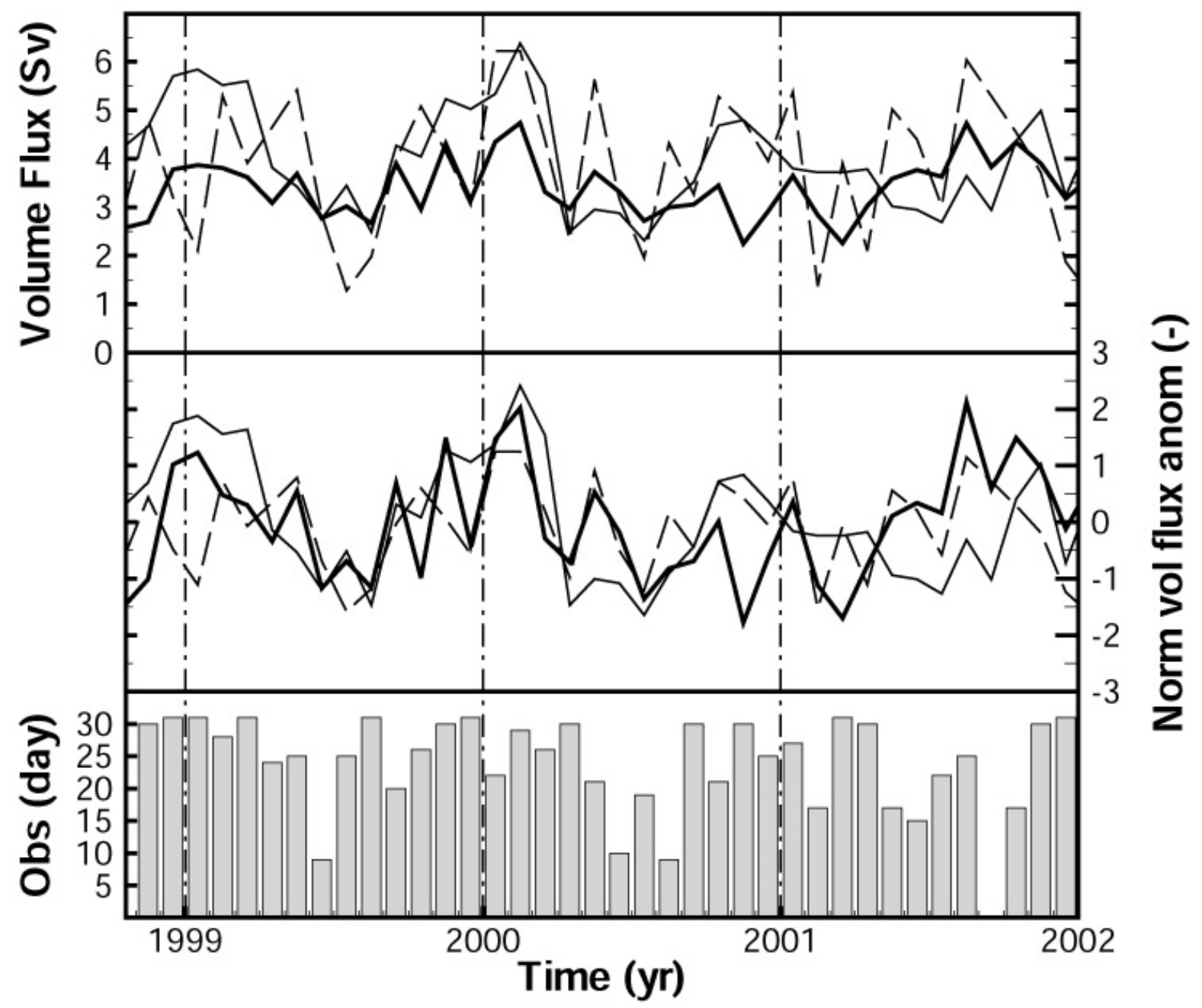

Figure 6. Observed and simulated northward volume transport through the Faroe-Shetland Channel. Upper panel: Observed transport (Sv) based on current meters [Østerhus et al., 2005] in dashed line, simulated NAOSIM (MICOM) transport (Sv) in thin (thick) solid line. Mid panel: Corresponding normalised volume flux anomalies, where normalization is done with respect to the standard deviation of the respective time series. Lower panel: The number of days with observations per month. The correlation between the observed time series and MICOM is 0.43 (significant at 99\% confidence level). The corresponding figure for NAOSIM is 0.26 at $90 \%$ confidence level (serial correlations are included in the analysis). 

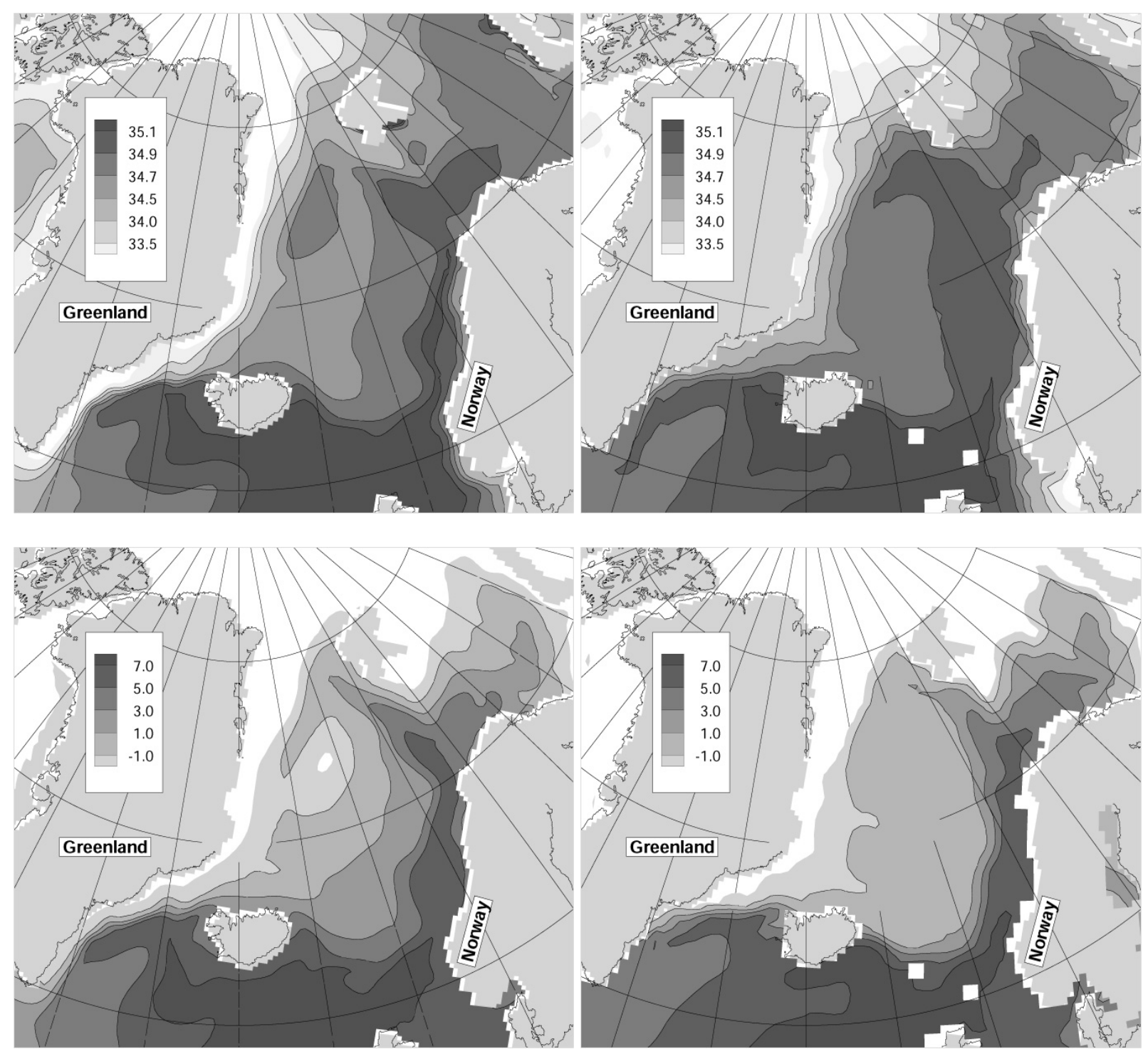

Figure 7. Simulated salinity (psu) (upper panels) and temperature $\left({ }^{\circ} \mathrm{C}\right.$ ) (lower panels) in March averaged over the uppermost $150 \mathrm{~m}$ of the water column for 1948-2002. NAOSIM at left and MICOM at right. 

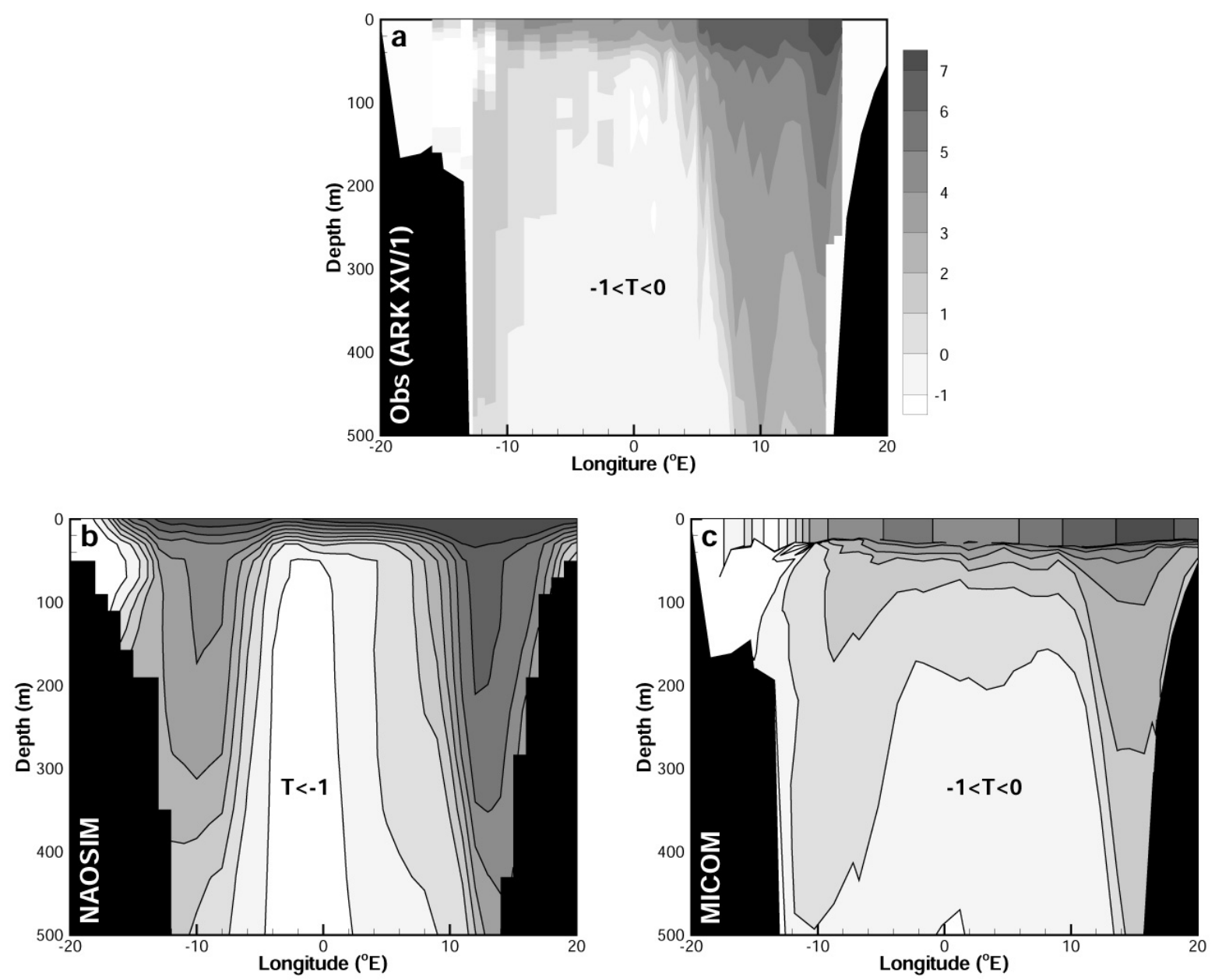

Figure 8. Observed (upper panel) and simulated temperature along $75^{\circ} \mathrm{N}$ in the Nordic Seas (NAOSIM to left, and MICOM to right). The observations are from cruise ARK XV/1 with RV Polarstern from 23 June-19 July 1999 [G. Budeus, pers. comm.]. The simulated fields are July monthly means. The same contouring is used for all panels. 

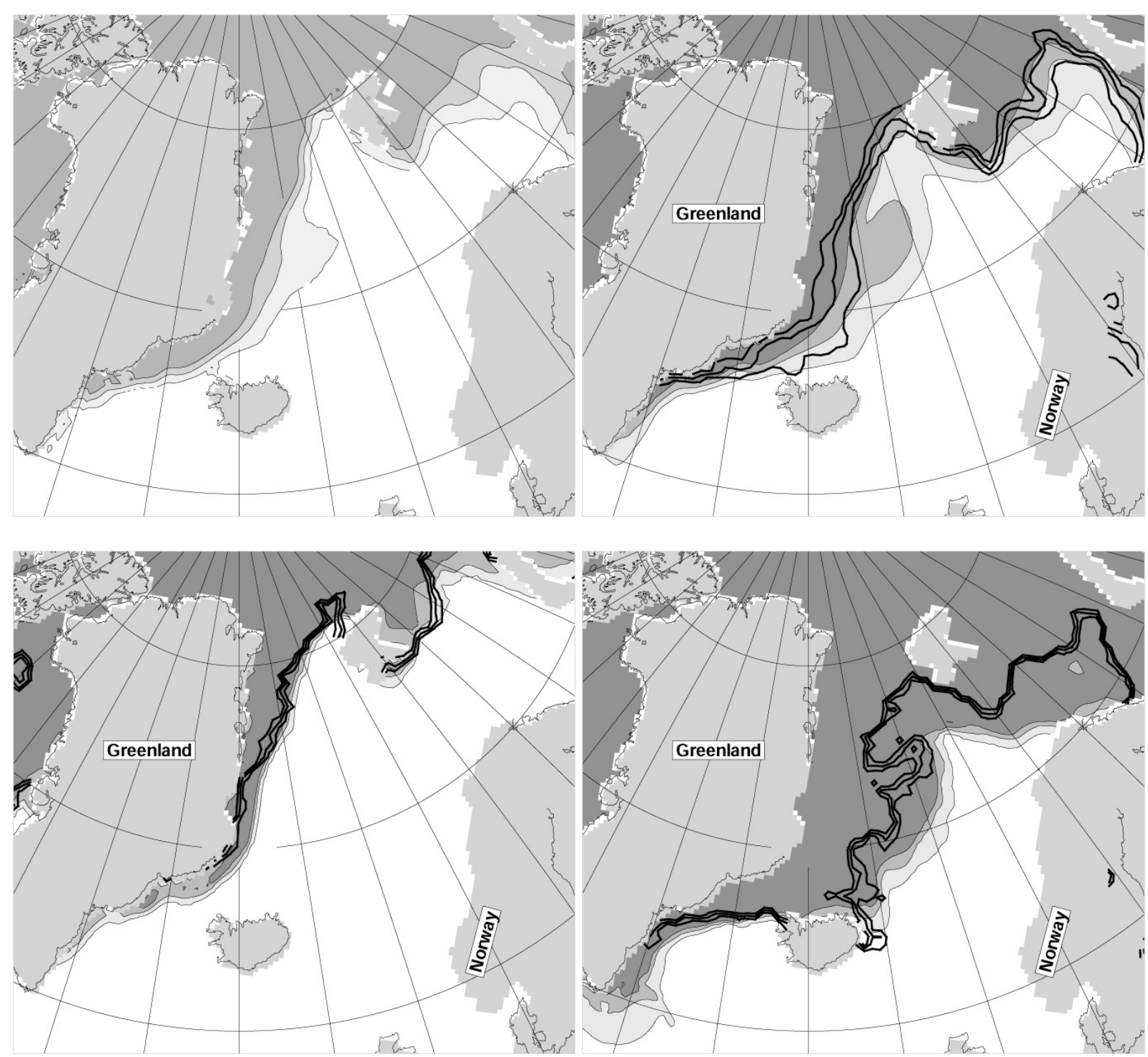

Figure 9. Mean sea ice concentration in March for 1978-2002 from observations (upper left panel) [Johannessen et al., 1999] and for 1948-2002 from the simulations (upper right panel). Simulated minimum (maximum) concentration is given in the lower left (right) panels. Observations and NAOSIM are shown with thin lines and shaded contour levels of $10 \%, 40 \%$ and $70 \%$, whereas MICOM is shown with thick solid lines with similar contour levels. 

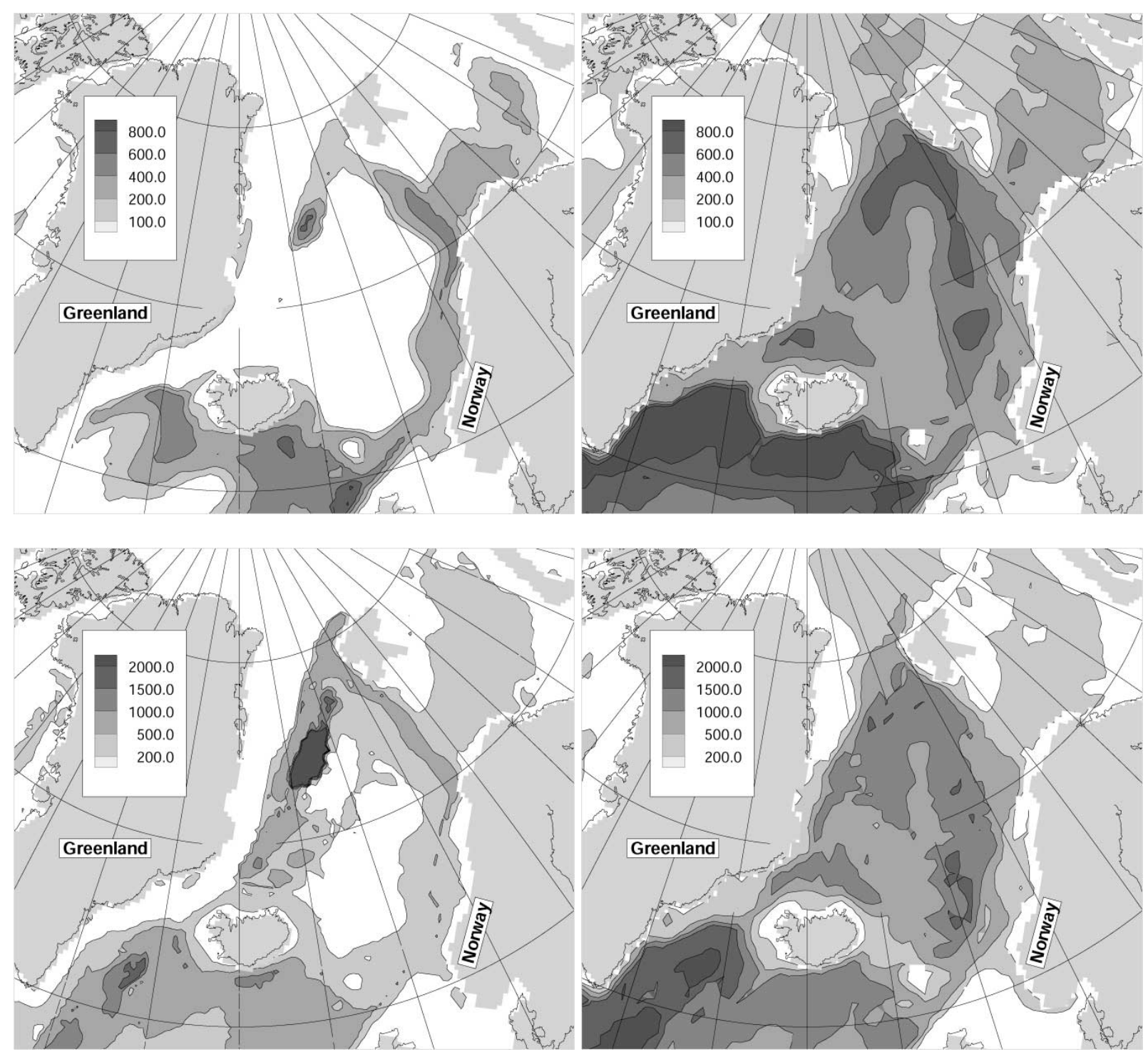

Figure 10. Simulated mean (upper panels) and maximum (lower panels) mixed layer depth (m) in March for the period 1948-2002. NAOSIM to left and MICOM to right. 